\title{
Modelled and observed changes in aerosols and surface solar radiation over Europe between 1960 and 2009
}

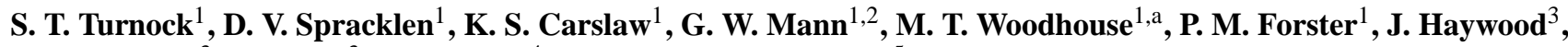 \\ C. E. Johnson ${ }^{3}$, M. Dalvi ${ }^{3}$, N. Bellouin ${ }^{4}$, and A. Sanchez-Lorenzo ${ }^{5}$ \\ ${ }^{1}$ Institute of Climate and Atmospheric Science, School of Earth and Environment, University of Leeds, Leeds, UK \\ ${ }^{2}$ National Centre for Atmospheric Science, University of Leeds, Leeds, UK \\ ${ }^{3}$ Met Office, Fitzroy Road, Exeter, Devon, UK \\ ${ }^{4}$ Department of Meteorology, University of Reading, Reading, UK \\ ${ }^{5}$ Pyrenean Institute of Ecology, Spanish National Research Council, Zaragoza, Spain \\ ${ }^{a}$ now at: CSIRO Ocean and Atmosphere, Aspendale, Victoria, Australia \\ Correspondence to: S. T. Turnock (s.t.turnock12@leeds.ac.uk)
}

Received: 2 April 2015 - Published in Atmos. Chem. Phys. Discuss.: 8 May 2015

Revised: 31 July 2015 - Accepted: 4 August 2015 - Published: 25 August 2015

\begin{abstract}
Substantial changes in anthropogenic aerosols and precursor gas emissions have occurred over recent decades due to the implementation of air pollution control legislation and economic growth. The response of atmospheric aerosols to these changes and the impact on climate are poorly constrained, particularly in studies using detailed aerosol chemistry-climate models. Here we compare the HadGEM3-UKCA (Hadley Centre Global Environment Model-United Kingdom Chemistry and Aerosols) coupled chemistry-climate model for the period 1960-2009 against extensive ground-based observations of sulfate aerosol mass (1978-2009), total suspended particle matter (SPM, 19781998), $\mathrm{PM}_{10}$ (1997-2009), aerosol optical depth (AOD, 2000-2009), aerosol size distributions (2008-2009) and surface solar radiation (SSR, 1960-2009) over Europe. The model underestimates observed sulfate aerosol mass (normalised mean bias factor $(\mathrm{NMBF})=-0.4)$, SPM $(\mathrm{NMBF}$ $=-0.9), \mathrm{PM}_{10}(\mathrm{NMBF}=-0.2)$, aerosol number concentrations $(\mathrm{N} 30 \mathrm{NMBF}=-0.85 ; \mathrm{N} 50 \mathrm{NMBF}=-0.65$; and $\mathrm{N} 100$ $\mathrm{NMBF}=-0.96)$ and $\mathrm{AOD}(\mathrm{NMBF}=-0.01)$ but slightly overpredicts SSR $(\mathrm{NMBF}=0.02)$. Trends in aerosol over the observational period are well simulated by the model, with observed (simulated) changes in sulfate of $-68 \%(-78 \%)$, SPM of $-42 \%(-20 \%), \mathrm{PM}_{10}$ of $-9 \%(-8 \%)$ and AOD of $-11 \%(-14 \%)$. Discrepancies in the magnitude of simulated aerosol mass do not affect the ability of the model to reproduce the observed SSR trends. The positive change in
\end{abstract}

observed European SSR (5\%) during 1990-2009 ("brightening") is better reproduced by the model when aerosol radiative effects (ARE) are included (3\%), compared to simulations where ARE are excluded (0.2\%). The simulated topof-the-atmosphere aerosol radiative forcing over Europe under all-sky conditions increased by $>3.0 \mathrm{~W} \mathrm{~m}^{-2}$ during the period 1970-2009 in response to changes in anthropogenic emissions and aerosol concentrations.

\section{Introduction}

Aerosols can cause acid deposition, degradation of atmospheric visibility, changes to Earth's radiative balance, and are also a major source of air pollution, which affects human health. Aerosols interact with climate by absorbing and reflecting incoming solar radiation and by modifying the microphysical properties of clouds. These effects have been defined in the latest Intergovernmental Panel on Climate Change (IPCC) report (Boucher et al., 2013) as aerosolradiation interactions (ARI) and aerosol-cloud interactions (ACI). Aerosols (also referred to as particulate matter (PM)) are detrimental to air quality and human health, as particles below a certain size can penetrate into the lungs causing respiratory and cardiovascular problems (COMEAP, 2010). Strategies that attempt to mitigate climate change and poor air quality are inherently connected and have the potential to 
induce both benefits and penalties for either depending on the particular species targeted (Arneth et al., 2009; Ramanathan and Feng, 2009; Fiore et al., 2012).

Here we use a global coupled chemistry-climate model to improve our understanding of changes in aerosols over Europe from 1960 to 2009. The climate impact of aerosols over this period, in response to emission changes, was calculated as an aerosol radiative forcing. An assessment of the confidence in this effect was obtained from the ability of the model to reproduce observed long-term changes in a number of aerosol properties including mass concentrations and aerosol optical depth (AOD).

Anthropogenic emissions of aerosol particles and their precursors have increased significantly since pre-industrial times. For example, global $\mathrm{SO}_{2}$ emissions have increased by a factor of 60 from the pre-industrial to a peak in the 1970s (Lamarque et al., 2010; Granier et al., 2011; Smith et al., 2011). However, from the 1980s onwards, regional reductions in anthropogenic emissions (mainly North America and Europe) have occurred due to air quality mitigation strategies, which has led to a decline in European $\mathrm{SO}_{2}$ emissions of $73 \%$ between 1980 and 2004 (Vestreng et al., 2007; Hand et al., 2012). Anthropogenic emissions of oxides of nitrogen $\left(\mathrm{NO}_{X}\right)$, carbon monoxide $(\mathrm{CO})$ and black carbon $(\mathrm{BC})$ have also decreased over Europe between 1980 and 2010 by 30, 58 and $55 \%$ respectively (Granier et al., 2011). Conversely, anthropogenic emissions from eastern Asia have increased due to population growth and economic development, leading to an increase in $\mathrm{SO}_{2}$ emissions of a factor of 7 from the 1960s to the present day (Smith et al., 2011).

Changes in anthropogenic emissions and aerosol concentrations affect Earth's climate (Arneth et al., 2009; Ramanathan and Feng, 2009; Fiore et al., 2012). The effect of past and future changes in emissions on aerosols and their associated climate impacts is uncertain (Penner et al., 2010; Chalmers et al., 2012). In addition, emission inventories of aerosols and their precursor species account for large uncertainty in models (de Meij et al., 2006). It is therefore important to understand and evaluate the changes to aerosol processes and properties that have occurred over recent decades where we have aerosol measurements.

Ground-based monitoring networks providing observations of aerosol concentrations and physiochemical properties were established following air pollution control legislation. The longest continuous measurements of aerosols are available in North America and Europe from the 1970s to present day. In Europe, observations of aerosol mass concentrations (both sulfate and total) are available from the European Monitoring and Evaluation Programme (EMEP) network (Tørseth et al., 2012) and similar data for North America are available from the Integrated Monitoring of Protected Visual Environments (IMPROVE) network (http: //vista.cira.colostate.edu/improve/). In addition, AOD has been monitored in Europe over the last decade by the groundbased Aerosol Robotic Network (AERONET) (Holben et al.,
1998). There are limitations in the spatial and temporal extent of the data from these networks, as well as in the consistency of the instrumental techniques used and components measured throughout the monitoring period. However, they do provide a useful source of multidecadal aerosol data with which to evaluate model predictions.

Several studies have analysed long-term trends in observed aerosols. Tørseth et al. (2012) used observations from the EMEP network to show a decline in sulfate aerosol mass from the 1970s to present day and a decline in $\mathrm{PM}_{10}$ (mass of particles with diameter $<10 \mu \mathrm{m}$ ) from 2000 to 2009 . Asmi et al. (2013) and Barmpadimos et al. (2012) reported a reduction in the aerosol number and mass concentration over the last 10-15 years across Europe. However, Collaud Coen et al. (2013) found no significant changes in aerosol optical properties over Europe for a similar period. Similarly, Harrison et al. (2008) analysed changes in aerosol mass concentrations over the UK and reported relatively stable concentrations over 2000-2010, even when emission reductions are anticipated to have occurred.

Evaluating the ability of chemistry-climate models to reproduce observed trends is necessary in order to reliably predict the climate effects of aerosols over this period. Many studies qualitatively match the direction of observed trends in aerosol but underestimate both absolute concentrations and the magnitude of observed trends (Berglen et al., 2007; Colette et al., 2011; Koch et al., 2011; Chin et al., 2014). Leibensperger et al. (2012) used the chemical transport model (CTM) GEOS-Chem to evaluate aerosol trends over the USA at decadal time slices and found that sulfate but not $\mathrm{BC}$ was represented well by the model. A multimodel assessment of aerosol trends in Europe over the last decade showed models successfully simulate observed negative trends in $\mathrm{PM}_{10}$ but fail to reproduce the positive trends observed at some locations and typically underestimate absolute concentrations (Colette et al., 2011). Observed reductions in sulfate over Europe have also been underestimated by other studies (Berglen et al., 2007; Koch et al., 2011). Over Europe, Skeie et al. (2011) reproduced the observed change in decadal average sulfate concentrations but overestimated nitrate aerosol concentrations.

Several studies (Lamarque et al., 2010; Shindell et al., 2013) have also assessed long-term changes in AOD. Lamarque et al. (2010) evaluated simulations of present day AOD against AERONET observations and reported a relatively good reproduction of interannual variability, except in regions of high AOD. Shindell et al. (2013) assessed AOD from the models involved in the Atmospheric Chemistry and Climate Model Intercomparison Project (ACCMIP) and showed that most captured the observed trends between 1980 and 2010 relatively well, although many were underpredicted in the present day, particularly over eastern Asia.

Changes in surface solar radiation (SSR) do not provide a direct measurement of aerosols but they can be used to infer their influence on the surface radiation balance.The Global 
Energy Balance Archive (GEBA) provides long-term observations of SSR from the 1950s until present day over a large part of Europe (Sanchez-Lorenzo et al., 2013). These measurements can also be used as a general measure to validate radiation balance predictions from global climate models against the observed surface variations. Such observations have shown that the European "dimming" period of the 1980s and the subsequent "brightening" period of the 1990s-2000s can be attributed partly to changes in clouds, concentrations of aerosols and aerosol-cloud effects (Wild, 2009). Model simulations have been evaluated against SSR observations and demonstrated issues in simulating the timing and magnitude of observed SSR trends. In an assessment of the models contributing to the 5th Coupled Model Intercomparison Project (CMIP5), Allen et al. (2013) showed that the dimming trend over Europe was underestimated in all models, potentially due to an under-represented aerosol direct effect. However, the CMIP5 models were able to reproduce the observed brightening trend. Folini and Wild (2011) performed transient simulations with ECHAM5-HAM over Europe (with interactive aerosols) and found that simulated reductions in SSR occurred too early in the model, whereas the increase in SSR was correctly timed. Using a regional climate model over Europe driven by reanalysis data, Chiacchio et al. (2015) overestimated SSR, simulated a premature onset of dimming and demonstrated that only simulations including aerosols were able to reproduce the observed brightening trend. In addition, Koch et al. (2011) simulated the correct interdecadal variability in SSR but underestimated the magnitude of observed SSR.

These previous studies have either simplified their treatment of aerosols or the model was evaluated against a limited range of aerosol properties over a relatively coarse spatial and temporal scale. The importance of studies at regional spatial scales was also highlighted as changes in aerosols at this level can potentially be masked by compensatory changes observed on the global scale. Here we simulate monthly-mean aerosol concentrations from 1960 to 2009 using the HadGEM3-UKCA (Hadley Centre Global Environment Model-United Kingdom Chemistry and Aerosols) global chemistry-climate model, which includes aerosol microphysics (aerosol number and mass size distributions). We evaluate the ability of the model to consistently capture observed changes in bulk in situ aerosol properties (PM, aerosol size distributions and chemical components) as well as radiative properties (AOD, SSR) over Europe. We also calculate the regional top of atmosphere radiative perturbations due to simulated changes in aerosols. This has enabled a detailed regional analysis and evaluation of the changing radiative impact of aerosols due to variations in emissions.

Section 2 describes the HadGEM3-UKCA model, the simulations performed and the long-term observations used. Section 3 discusses and evaluates the simulated changes to European aerosols and surface solar radiation. Section 4 presents aerosol radiative forcing over Europe. Conclusions are presented in Sect. 5.

\section{Methods}

\subsection{Model description and simulations}

\subsubsection{General}

We used the coupled chemistry-climate model HadGEM3UKCA to study the interaction between chemistry, aerosols and the impacts on the radiation balance of the climate system. HadGEM3-UKCA is part of the third generation of the Met Office's Hadley Centre Global Environment Model (HadGEM) family, which incorporates an online treatment of chemistry and aerosols through the United Kingdom Chemistry and Aerosols (UKCA) programme. The Met Office Unified Model (UM) acts as the dynamical core and provides the components for atmospheric transport and tracer mixing. This is based on the dynamics implemented by Davies et al. (2005) and includes processes such as large-scale advection, convective uplift and boundary layer mixing. A description of the atmosphere-only version of HadGEM3 is provided in Hewitt et al. (2011). Morgenstern et al. (2009) and O'Connor et al. (2014) describe the incorporation and evaluation of UKCA into HadGEM.

HadGEM3-UKCA is used here in atmosphere-only mode. We output monthly 3-D aerosol and radiation fields for the years $1960-2009$ at a resolution of $1.875^{\circ} \times 1.25^{\circ}$ (approximately $140 \mathrm{~km}$ at mid latitudes) with 63 vertical levels up to $40 \mathrm{~km}$. The 3-D meteorological fields were nudged at $6 \mathrm{~h}$ intervals to the European Centre for Medium-Range Weather Forecasts (ECMWF) Reanalysis (ERA-40) (Uppala et al., 2005) for the years 1960-2000 and ERA-Interim (Dee et al., 2011) for 2000-2009. Sea surface temperatures and sea ice fields were prescribed in accordance with those used in CMIP5 (Hurrell et al., 2008). Coupling between the land surface and atmosphere was simulated using the Met Office Surface Exchange Scheme (MOSES; Essery et al., 2002). By nudging to reanalysis data, we ensure that the model produces a realistic representation of the meteorological conditions under which aerosol observations were taken.

Tropospheric ozone, $\mathrm{HO}_{X}, \mathrm{NO}_{X}$ and VOC (volatile organic compounds) chemistry was calculated using the mechanism described by O'Connor et al. (2014), which includes reactions of odd oxygen $\left(\mathrm{O}_{X}\right)$, nitrogen $\left(\mathrm{NO}_{Y}\right)$, hydrogen $\left(\mathrm{HO}_{X}=\mathrm{OH}+\mathrm{HO}_{2}\right)$ and $\mathrm{CO}$, as well as methane and other short chain non-methane VOCs. The scheme has been extended to include additional sulfur (Mann et al., 2010), monoterpene (Spracklen et al., 2006) and isoprene (Scott et al., 2014) chemistry.

The Fast-J photolysis scheme is implemented within UKCA to calculate online photolysis rates based on the distribution of clouds, ozone and aerosols (Wild et al., 2000). 
Dry and wet deposition of gas-phase species is described in O'Connor et al. (2014).

HadGEM3-UKCA uses the modal aerosol scheme of the Global Model of Aerosol Processes (GLOMAP mode) (Mann et al., 2010). GLOMAP mode uses log-normal modes to represent the aerosol size distribution and simulates the evolution of the size-resolved number and mass of aerosol particles with different compositions. GLOMAP simulates the interaction of various aerosol processes including sizeresolved primary emissions, cloud processing, new particle formation, hygroscopic growth, coagulation, condensation, deposition and scavenging. Log-normal modes are used to represent aerosols in the nucleation (diameter $(D)<10 \mathrm{~nm}$ ), Aitken ( $D$ 10-100 nm), accumulation $(D 100 \mathrm{~nm}-1 \mu \mathrm{m})$ and coarse $(D>1 \mu \mathrm{m})$ modes. In this study the model is set up to simulate sulfate, $\mathrm{BC}$, organic carbon (OC) and sea salt aerosol in five different modes (four soluble and one insoluble Aitken modes). Secondary organic aerosol (SOA) is formed from products of monoterpene oxidation, which are generated at $13 \%$ yield and assumed to be involatile (Spracklen et al., 2006). There is no representation of ammonium nitrate in this version of the model. Mineral dust is simulated using a separate six-bin scheme developed by Woodward (2001) and covers particle sizes from 0.03 to $30 \mu \mathrm{m}$ in radius.

\subsubsection{Aerosol radiative effects}

The Edwards-Slingo radiation code (Edwards and Slingo, 1996) calculates changes in Earth's radiation balance from chemical and aerosol species. ARI (aerosol direct effects) are calculated according to Bellouin et al. (2013) from waveband-averaged scattering and absorption coefficients obtained from modelled size distributions and a volumeweighted average of component refractive indices within each mode. GLOMAP-mode provides the aerosol fields for the calculation of ACI online within the model, in accordance with that described in Bellouin et al. (2013). Simulated cloud condensation nuclei $(\mathrm{CCN})$ concentrations are used to calculate cloud droplet number (CDN) concentrations based on the empirical relationship derived by Jones et al. (2001). The cloud albedo effect is calculated using simulated CDN. The coupling of UKCA to the precipitation scheme potentially allows for the effect of aerosols on cloud lifetime (rapid adjustments for ACI) to be diagnosed. This can be done by calculating the influence they have on CDN concentrations, cloud effective radius and ultimately the auto-conversion of cloud drops to precipitation, as described in Jones et al. (2001). However, in this study, because we nudge to reanalysis fields, the changes in the radiative balance due to aerosols are not allowed to feedback on to the meteorology.

The radiation scheme was called twice for each time step (every $30 \mathrm{~m}$ ) in a double-call radiation configuration (Bellouin et al., 2013). The first call uses the modelled aerosol fields and the second call uses an aerosol-free atmosphere for the clear-sky radiative calculation and a prescribed default CDN field (based on an aerosol climatology) for the cloud radiation calculation. This approach therefore eliminates the model's radiatively-driven response to changes in aerosols, enabling the radiative forcing from ARI and ACI to be calculated with no rapid adjustments to clouds permitted from either effect. Here we calculate an aerosol radiative forcing (only from the direct and first indirect effects) as the difference between monthly values in each year of the simulation and the monthly mean aerosol radiative state in the period 1980-2000. An estimate of the cloud albedo effect (first aerosol indirect) can be obtained by subtracting the radiative effect obtained under all-sky conditions from those under clear skies.

\subsubsection{Aerosol emissions}

Sea salt emissions are calculated using the surface wind speed and the parameterisation of Gong (2003). Emissions from tropospheric volcanoes (both continuous and explosively erupting) are included from Andres and Kasgnoc (1998) and Halmer et al. (2002) using the AEROCOM recommendations. Dimethyl sulfide (DMS) emissions are calculated from monthly seawater concentration fields (Kettle and Andreae, 2000) and a wind speed dependent airsea exchange parameterisation (Liss and Merlivat, 1986). Wildfire (biomass burning) emissions are from the MACCity (MACC/CityZEN EU projects) inventory (Granier et al., 2011) for 1980-2009 and from the RETRO inventory from 1960 to 1980 (Schultz et al., 2008). Monoterpene emissions from vegetation are prescribed as monthly mean fields from Guenther et al. (1995). Dust emissions from the surface are calculated online using a six-bin scheme (Woodward, 2001) and depend on the particle size distribution of the soil, surface soil type (represented by a bare soil fraction), soil moisture and wind speed. Dust is emitted when the wind speed exceeds a threshold value and if the soil moisture is below a certain level.

Monthly mean anthropogenic emissions of $\mathrm{CO}, \mathrm{SO}_{2}$, $\mathrm{NO}_{X}, \mathrm{OC}$ and $\mathrm{BC}$ from 1960 to 2009 are taken from the MACCity inventory (Granier et al., 2011). Emissions are provided at a $0.5^{\circ}$ by $0.5^{\circ}$ resolution and are based on those from ACCMIP and the IPCC Reference Concentration Pathway (RCP) scenario 8.5 for energy, transportation, industry, shipping, agriculture, residential and waste sectors.

Figure 1 shows the European and regional domains used throughout this study. Figure 2 shows the emissions of $\mathrm{SO}_{2}$, $\mathrm{OC}, \mathrm{BC}, \mathrm{NH}_{3}$ and $\mathrm{NO}_{X}$ across Europe from the MACCity inventory between 1960 and 2009. Anthropogenic emissions of $\mathrm{SO}_{2}$ over the European domain have increased from $33 \mathrm{Tg} \mathrm{yr}^{-1}$ in 1960 to a peak of $46 \mathrm{Tg} \mathrm{yr}^{-1}$ in 1980 before decreasing at a relatively constant rate to $11 \mathrm{Tg} \mathrm{yr}^{-1}$ in 2009 (Fig. 2a). Between 1980 and 2009, European anthropogenic $\mathrm{SO}_{2}$ emissions in this data set declined by $70 \%$, in agreement with previous assessments (Vestreng et al., 2007; Tørseth 
et al., 2012). The emissions of $\mathrm{NO}_{X}$ have decreased by $20 \%$ and followed a similar temporal trend to $\mathrm{SO}_{2}$. A continuous decline in BC and OC emissions occurred from the 1960s to present day, due to reductions in the residential sector, partially offset by recent increases from the transportation sector. The emissions of $\mathrm{NH}_{3}$ across Europe (not used as part of the aerosol scheme in this study due to the absence of ammonium nitrate) increased continuously over the period 1960-2009, driven largely by the agriculture sector.

Figure $2 b-f$ show the annual emissions of each species from the MACCity inventory across the individual European regions. Emissions of OC (Fig. 2f) and $\mathrm{SO}_{2}$ (Fig. 2b) have decreased across all the different European regions. Emissions of $\mathrm{NO}_{X}$ and BC (Fig. 2c, e) increase until the 1980s1990s before declining across all regions, except in southern Europe. Anthropogenic emissions from northern and central Europe have declined from the 1980s onwards, whereas emissions from southern Europe have either increased or remained unchanged.

\subsection{Observations}

Ground-based measurements of aerosols used in this study are listed in Table 1 and include aerosol mass concentrations (sulfate and total mass) from the EMEP network (http:// www.emep.int), AOD from AERONET (http://aeronet.gsfc. nasa.gov/), aerosol size distributions from EUSAAR (European Supersites for Atmospheric Aerosol Research) and GUAN (German Ultrafine Aerosol Network) (Asmi et al., 2011) and SSR from the GEBA database (http://www.geba. ethz.ch/history/index). All data used in this study are presented as either monthly or annual averages. Figure 1 shows the location of all the measurement sites along with the five regions of Europe. Figure 3 shows the temporal evolution in the number of measurement sites used in this analysis for each observation. We note that the number of locations reporting sulfate and SSR has declined since 2000.

\subsubsection{EMEP observations}

The EMEP network has reported the concentrations of sulfate and total aerosol mass at locations across Europe from 1978 until present day (Tørseth et al., 2012). Measurements of total suspended particle matter (SPM) are an early measure of particulate matter and available from 1978 to 2005, with most measurements from Germany, Switzerland and Spain. However, only measurements up to and including 1998 are used due to the reduced availability of data in the period 1999-2005 (Fig. 3). The SPM measurements cover all particle sizes and may be influenced by local sources of very large particles (diameter $>10 \mu \mathrm{m}$ ). Measurements of $\mathrm{PM}_{10}$ are available from EMEP from 1996 until present day. Sulfate aerosol mass measurements are available from 1978 until present day.
We used sulfate aerosol mass, $\mathrm{PM}_{10}$ and total SPM from the sites that have been continuously operating for more than 5 years (Fig. 1a). The measurements were made using different measurement techniques and time frequencies (hourly and daily). The raw data were screened to remove any anomalous data points according to the flag in the original data records. Monthly and annual mean values were then calculated from the screened data for sites that had more than $75 \%$ of measurements in the averaging period.

\subsubsection{Aerosol size distribution}

Aerosol size distribution data over Europe from the EUSAAR and GUAN ground-based monitoring sites have previously been collected and processed by Asmi et al. (2011) over the period 2008-2009. Here we use the same 17 low altitude sites as in the multimodel comparison by Mann et al. (2014) to compare modelled and observed aerosol number concentrations at three different size fractions $(>30 \mathrm{~nm}$ (N30), $>50 \mathrm{~nm}(\mathrm{~N} 50)$ and $>100 \mathrm{~nm}(\mathrm{~N} 100)$ dry diameter) over the period 2008-2009.

\subsubsection{AOD}

The AERONET program is a ground-based network of sun photometers, currently with more than 200 sites providing aerosol optical, microphysical and radiative properties (Holben et al., 1998). Observed AOD values are available over Europe from the mid-1990s but most sites only started operating within the last 10 years (Fig. 3) and there are relatively few consistent long-term data sets available before 2000. We used the Level 2.0 data product (cloud-screened and quality assured) from 20 sites that have been operating for longer than 5 years over Europe between 2000 and 2009. AOD measurements have the best record for wavelengths of 440,500 and $675 \mathrm{~nm}$. We used the $440 \mathrm{~nm}$ wavelength as it has the best spatial and temporal coverage.

\subsubsection{Surface solar radiation}

GEBA contains worldwide measurements of energy fluxes at the surface from more than 2000 sites, with the highest density over Europe. Monthly mean values of incident SSR (expressed as mean irradiance, in $\mathrm{W} \mathrm{m}^{-2}$ ) have been obtained from 56 sites across Europe starting before the 1970s, provided by Sanchez-Lorenzo et al. (2013), and include more than 20 sites that have data in the 1960s. The length of this observational record enabled the model evaluation to be extended prior to the availability of sulfate data. These measurements therefore enable an indirect evaluation of aerosol changes in the model across the entire time period of the simulations and also the validation of how changes in aerosols can affect Earth's radiation balance. 
a)

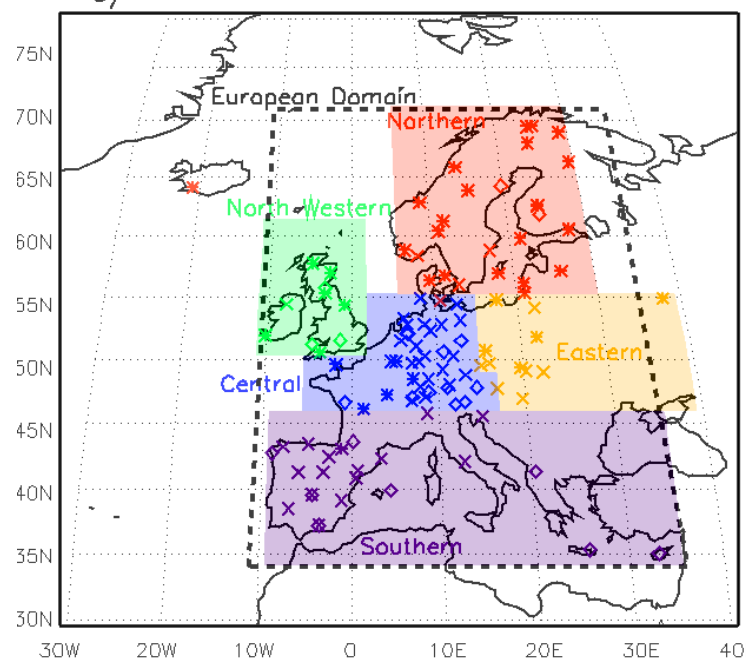

b)

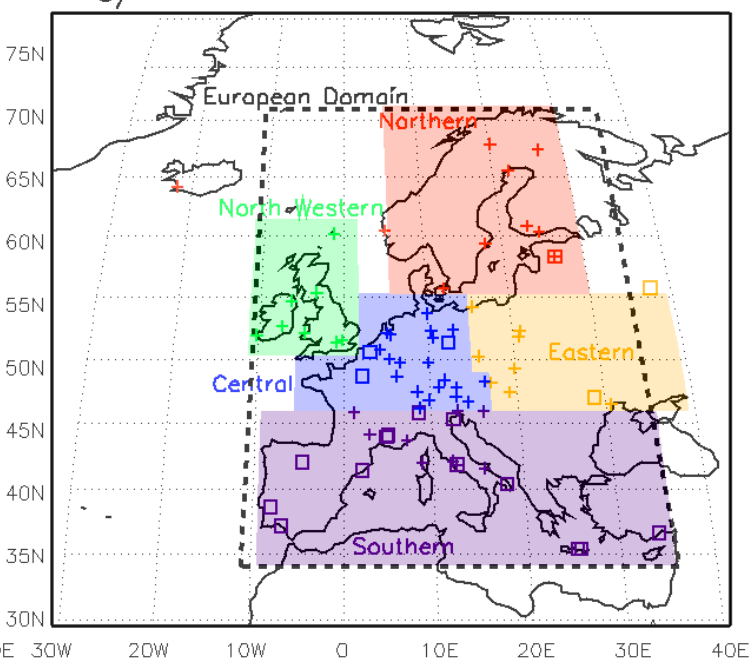

Figure 1. Location of measurements used in this study for (a) sulfate aerosol mass $(*)$, total aerosol mass $(\diamond)$ and sites that have measured both $(\times)$, (b) AOD $(\square)$ and surface solar radiation (+). Regional European definitions are north-western Europe (green), northern Europe (red), central Europe (blue), eastern Europe (orange) and southern Europe (purple).

a) All Europe

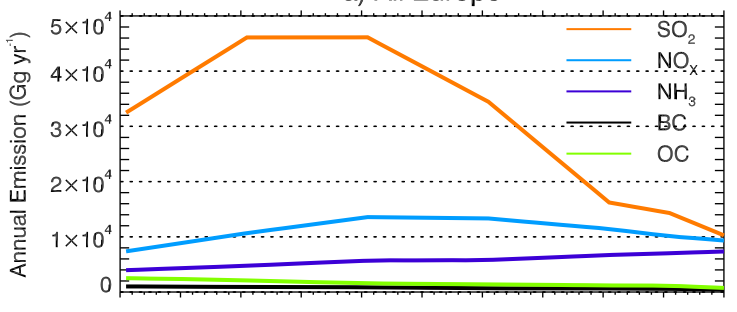

19601965197019751980198519901995200020052010

c) $\mathrm{NO}_{\mathrm{x}}$

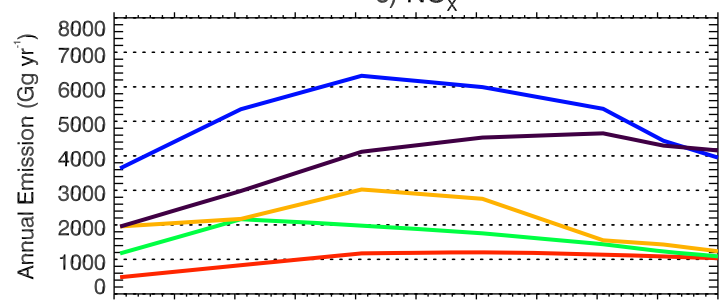

19601965197019751980198519901995200020052010

e) $\mathrm{BC}$

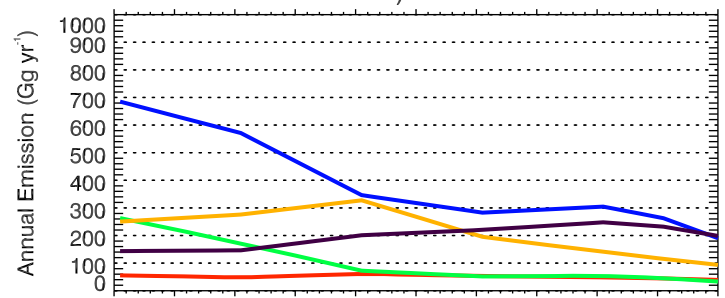

19601965197019751980198519901995200020052010 Date b) $\mathrm{SO}_{2}$

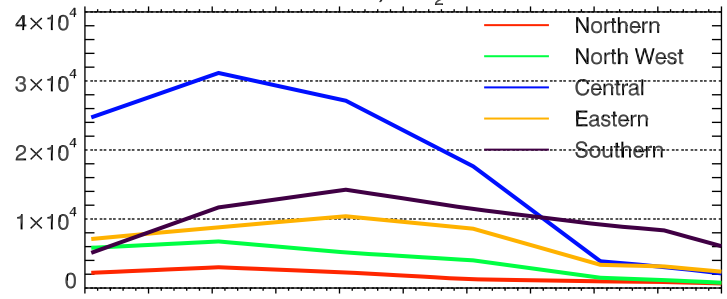

19601965197019751980198519901995200020052010

d) $\mathrm{NH}_{3}$

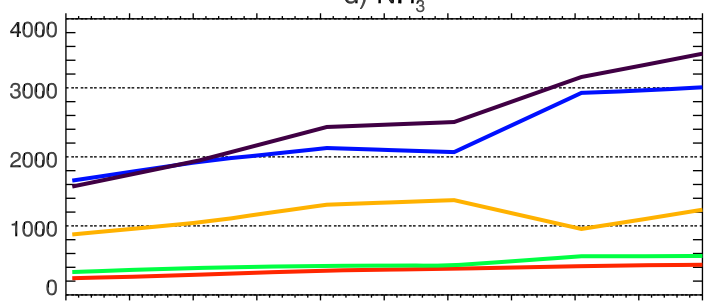

19601965197019751980198519901995200020052010

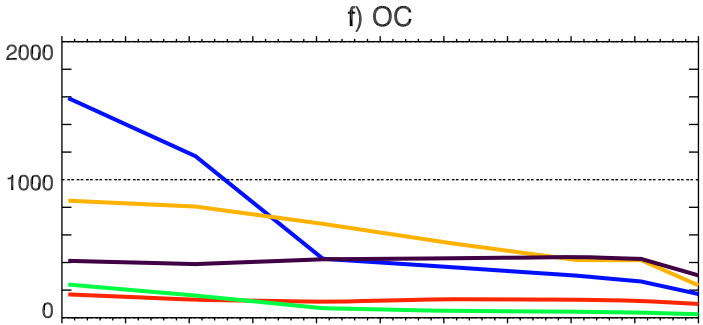

19601965197019751980198519901995200020052010 Date

Figure 2. Annual European emissions $\left(\mathrm{Gg} \mathrm{yr}^{-1}\right)$ of aerosols and aerosol precursors from the MACCity inventory over the period $1960-2009$. (a) Total European emissions of sulfur dioxide $\left(\mathrm{SO}_{2}\right.$, orange), organic carbon (OC, light green), black carbon (BC, black), ammonia (NH 3 , light purple) and oxides of nitrogen $\left(\mathrm{NO}_{X}\right.$, blue). (b)-(f) show European regional emissions for (b) $\mathrm{SO}_{2},(\mathbf{c}) \mathrm{NO}_{X}$, (d) $\mathrm{NH}_{3}$, (e) $\mathrm{BC}$ and (f) OC. Regions are as defined in Fig. 1: northern (red), north-western (green), central (blue), eastern (orange), southern (purple). 
Table 1. Details of the ground-based observations used in this study.

\begin{tabular}{|c|c|c|c|}
\hline $\begin{array}{l}\text { Data } \\
\text { source }\end{array}$ & Measurements & Period & $\begin{array}{l}\text { Total number of } \\
\text { sites available }\end{array}$ \\
\hline EMEP & total sulfate aerosol mass concentrations & 1978-2009 & 97 \\
\hline EMEP & total suspended particle mass concentrations & 1978-2005 & 42 \\
\hline EMEP & $\mathrm{PM}_{10}$ mass concentrations & 1996-2009 & 52 \\
\hline EUSAAR and GUAN & $\begin{array}{l}\text { aerosol number concentrations greater than } 30 \mathrm{~nm} \\
(\mathrm{~N} 30), 50 \mathrm{~nm}(\mathrm{~N} 50) \text { and } 100 \mathrm{~nm}(\mathrm{~N} 100) \text { in dry diameter }\end{array}$ & 2008-2009 & 24 \\
\hline AERONET & aerosol optical depth (AOD) & 1994-2009 & 21 \\
\hline GEBA & surface solar radiation (SSR) & 1928-2009 & 50 \\
\hline
\end{tabular}

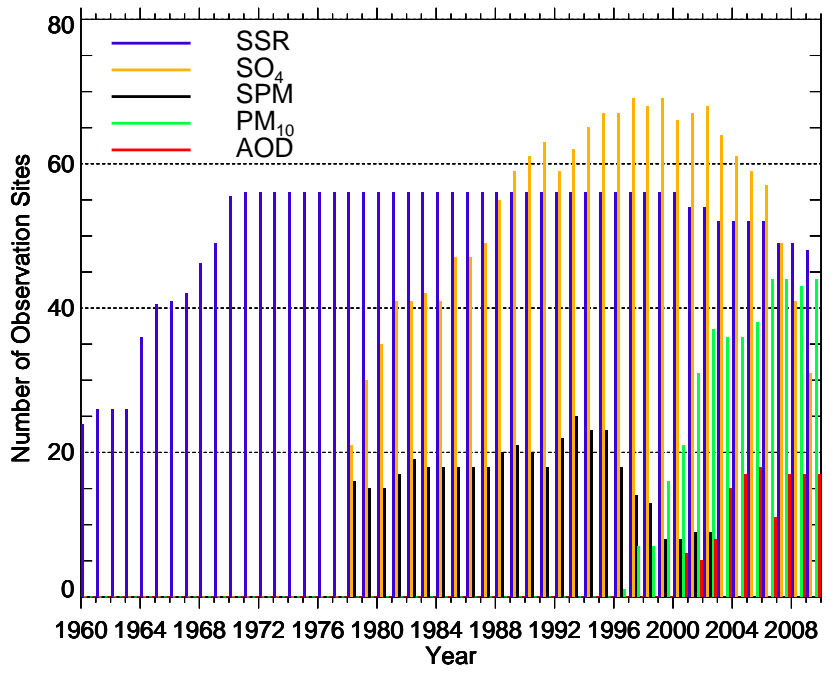

Figure 3. Temporal variation in the number of locations measuring surface solar radiation (SSR), sulfate aerosol mass $\left(\mathrm{SO}_{4}\right)$, total suspended particle mass (SPM), $\mathrm{PM}_{10}$ mass and aerosol optical depth (AOD).

\subsection{Model evaluation metrics}

Comparisons were made using monthly and annual mean values at individual monitoring locations and also across Europe as a whole. Model values were linearly interpolated to each measurement site using the relative contribution from the four closest surrounding model grid squares. The absolute and percentage change in the simulated and observed values of sulfate, SPM, PM 10 , AOD and SSR were calculated as the difference between the mean of the initial 5 years and the most recent 5 years of data.

The temporal trend in simulated and observed data was calculated by fitting an ordinary least squares linear model to the data using the function

$Y_{i}=a+b X_{i}(i=1, \ldots, n)$

The standard error (SE) of the trend line was used to provide an assessment of the error. For each simulated and observed trend, \pm two SE in the gradient was applied to provide an uncertainty range. Firstly, the standard deviation of the residuals $(\sigma)$ was determined and then used to calculate the SE.

The simulated temporal trends were evaluated by comparing against observed trends; if the gradient of the simulated and observed trends are within \pm two SE of each other we considered them to be similar.

An assessment of model accuracy is provided here by calculating the normalised mean bias factor (NMBF) of the model when compared to the observations (Yu et al., 2006). This metric is symmetric (i.e. not biased towards underprediction or overprediction) and is not biased when a low number of observed values are used. It is defined as

$\mathrm{NMBF}=S[\exp (|\ln (\bar{M} / \bar{O})|)-1]$,

where

$S=(\bar{M}-\bar{O}) /|\bar{M}-\bar{O}|$.

where $M$ represents the model values and $O$ represents the observed values. The sign of the NMBF indicates whether the model underestimates (negative) or overestimates (positive) the observed values. For a negative NMBF, the model values are a factor of $1-\mathrm{NMBF}$ below the observed values and for a positive NMBF the model values are a factor of $1+\mathrm{NMBF}$ above the observations (Yu et al., 2006). That is, $\mathrm{NMBF}=-0.5$ means the model is a factor 1.5 low biased and NMBF $=0.5$ means the model is a factor 1.5 high biased.

The goodness of fit between the model and observations is obtained by calculating the square of the linear Pearson correlation coefficient. A measure of the difference between model and observational values is provided by calculating the root mean square error (RMSE).

\section{Results}

\subsection{Simulated european aerosols and surface solar radiation from 1960 to 2009}

Figure 4a shows the simulated European (land only) mass concentrations of the different aerosol components over the 
period 1960-2009. Simulated $\mathrm{PM}_{10}$ declines from the early 1980s until 2009, coinciding with the reduction in anthropogenic emissions (Fig. 2). Continually decreasing mass concentrations of BC and OC are simulated between 1960 and 2009. Simulated sulfate mass concentrations increase from 1960 to a peak around 1980 and decrease thereafter.

Figure $4 \mathrm{~b}$ shows the change in simulated European surface aerosol number concentrations over the total, N30, N50 and N100 size fractions between 1960 and 2009. Aerosol number concentrations across all size fractions increase from 1960 to a peak in 1970 before declining to concentrations that are $50 \%$ lower in 2009.

Simulated European AOD (Fig. 4c) increases from 1960 to a peak in 1973 before decreasing till 2009 to an AOD that is lower than that simulated 1960. Figure 4d shows that simulated European SSR decreases from 1960 to 1980 (dimming) and then increases until 2009 (brightening).

\subsection{Model evaluation}

\subsubsection{Sulfate aerosol mass}

Figure 5a-d compare simulated single year annual mean sulfate concentrations over Europe for 1980, 1990, 2000 and 2009 against observations. Observed and simulated annual mean European sulfate aerosol concentrations declined by 68 and $78 \%$ respectively over the period 1978-2009 (Table 2). In 1980 (Fig. 5a) simulated and observed sulfate concentrations were largest in central Europe. In 2000 and 2009 (Fig. 5c, d) both simulated and observed sulfate concentrations in central Europe declined substantially, with the largest simulated concentrations over south-eastern Europe.

The model underestimates European annual mean sulfate aerosol mass concentrations in the period 1978-2009 $(\mathrm{NMBF}=-0.384$, Table 2$)$, with summertime concentrations overestimated $(\mathrm{NMBF}=0.694)$ and wintertime concentrations underestimated $(\mathrm{NMBF}=-2.19)$. Figure 6 shows the range of model bias in seasonal sulfate across European regions for the period 1978-2009. In summer, observed sulfate is underestimated by the model at the start of the period before coming into closer agreement towards the end of the period (Figs. 5e, 6). The model underestimates observed summertime sulfate across northern and southern Europe (NMBF between 0 and -1 ), and overestimates sulfate in central and eastern Europe (NMBF $<1)$. The model consistently underestimates wintertime sulfate (NMBF of -1 to -6) across all the European regions, with the largest discrepancy occurring in northern Europe.

An underprediction of wintertime European sulfate concentrations has been previously reported and may be due to an underestimation of oxidants in the model (Berglen et al., 2007; Manktelow et al., 2007; Langmann et al., 2008). In wintertime over northern Europe, the region with largest model bias, low concentrations of $\mathrm{H}_{2} \mathrm{O}_{2}$ limit incloud aqueous-phase oxidation of $\mathrm{SO}_{2}$. Under these condi- tions, oxidation by ozone is the dominant sulfate formation mechanism (Kreidenweis, 2003). We hypothesise that oxidation by ozone could be under-represented in the model, resulting in an underestimation of wintertime sulfate. This will be explored further in a future publication. Model underestimation could also be due to an artificially high wet deposition rate of sulfate, caused by an enhanced occurrence of drizzle precipitation within this version of the model (Walters et al., 2011).

Although the model underestimates absolute sulfate concentrations, the simulated trend over the period 1978-2009 $\left(-0.04 \pm 0.002 \mu \mathrm{g} \mathrm{S} \mathrm{m}^{-3} \mathrm{yr}^{-1}\right)$ is in good agreement with the observed trend $\left(-0.05 \pm 0.002 \mu \mathrm{g} \mathrm{S} \mathrm{m}^{-3} \mathrm{yr}^{-1}\right)$, at least on a European-wide annual mean basis (Fig. 5e). These trends can be considered similar as they are within two standard errors of each other. The largest decline in both simulated and observed sulfate concentrations occurred during 1980-2000, when average concentrations changed by $-0.05 \mu \mathrm{g} \mathrm{S} \mathrm{m}^{-3} \mathrm{yr}^{-1}$. Between 1980 and 2000, average simulated and observed concentrations declined by $50-60 \%$, corresponding to a 60-70\% decrease in anthropogenic emissions of $\mathrm{SO}_{2}$ (Fig. 2). A smaller reduction in sulfate aerosol mass of $13-18 \%$ was simulated and observed in the period 2000-2009, when average concentrations changed by $-0.015 \mu \mathrm{g} \mathrm{S} \mathrm{m}{ }^{-3} \mathrm{yr}^{-1}$. Figure 7 compares the simulated and observed linear trends in sulfate concentrations at all measurement locations. The model reproduces the observed linear trends in the annual mean concentrations. However, linear trends in wintertime sulfate aerosol mass are underestimated (by a factor of 3) but overestimated in summertime (by a factor of 1.3). This corresponds with the calculated NMBFs for winter and summertime mass concentrations, which showed an under- and overprediction respectively.

\subsubsection{Total aerosol mass}

Figure $8 \mathrm{a}$ and $\mathrm{b}$ compare simulated and observed annual mean total SPM concentrations over Europe in 1980 and 1990. The spatial changes in SPM over this period are less distinct than for sulfate. Simulated and observed SPM decreases over central Europe and increases over eastern Europe between 1980 and 1990. In contrast to sulfate aerosol mass, the simulated $20 \%$ decrease in SPM mass concentrations in the period 1978-1998 is considerably lower than the $50 \%$ observed decrease.

The model underpredicts the observed European annual mean SPM mass concentrations, with a NMBF of -0.88 in the period 1978-1998 (Table 3). A consistent underprediction of observed SPM concentrations was modelled across all European regions in both summer and winter (Fig. 9a). The model substantially underpredicts SPM concentrations in wintertime for southern and eastern Europe (NMBF of -8 to -0.5 ). In summertime and across all European regions the model underpredicts observations by a smaller amount (NMBF of 0 to -2 ). The large underprediction of 

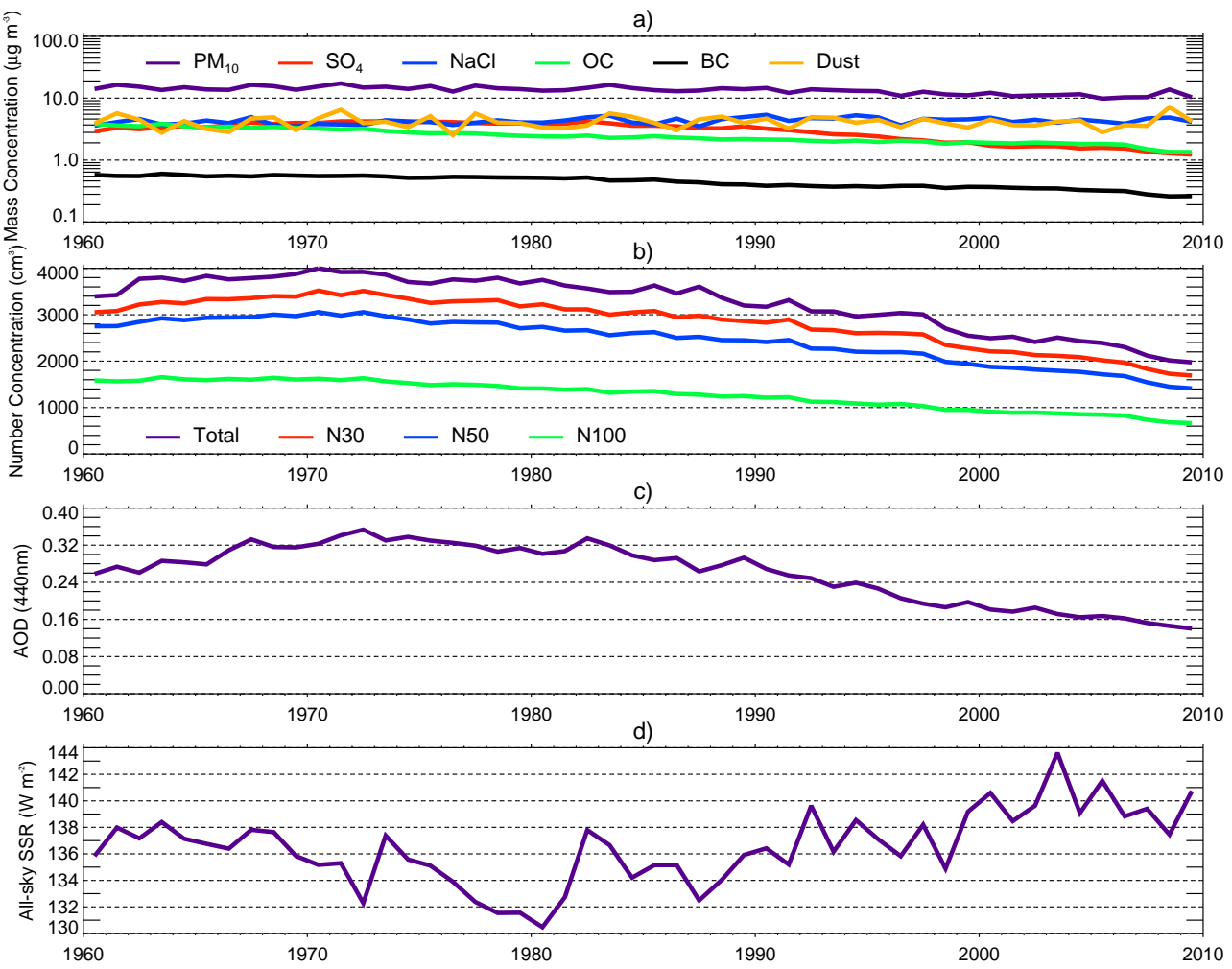

Figure 4. Simulated European annual mean (a) $\mathrm{PM}_{10}$ and composition-resolved surface mass concentration; (b) aerosol number concentration for particles with dry diameter > 3 (total), > 30 (N30), > 50 (N50) and > $100 \mathrm{~nm}$ (N100); (c) AOD at $440 \mathrm{~nm}$; and (d) SSR between 1960 and 2009. Mean values are calculated over the European land domain shown in Fig. 1.

Table 2. Statistical summary of modelled and observed annual and seasonal (DJF and JJA) mean sulfate at all long-term ( $>20$ years data) measurement sites (34 sites) between 1978 and 2009. Absolute and relative (\%) changes in concentrations are calculated as the difference between the mean of the initial 5 years of data minus the mean of the last 5 years of data. Trends that are above or below the value of twice of the standard error of the trend (95\% confidence) are highlighted in bold.

\begin{tabular}{|c|c|c|c|c|c|c|c|c|c|c|}
\hline Component & Type & $\begin{array}{r}\text { Absolute change } \\
\text { in concentration } \\
\left(\mu \mathrm{g} \mathrm{S} \mathrm{m}^{-3}\right)\end{array}$ & $\begin{array}{r}\text { Standard deviation } \\
\text { of mean value }\end{array}$ & $\begin{array}{l}\% \text { Change in } \\
\text { concentration }\end{array}$ & $\begin{array}{r}\text { Calculated } \\
\text { linear trend } \\
\left(\mu \mathrm{g} \mathrm{S} \mathrm{m}{ }^{-3} \mathrm{yr}^{-1}\right)\end{array}$ & $\begin{array}{l}-2 * \mathrm{SE} \\
\text { of trend }\end{array}$ & $\begin{array}{l}+2 * \mathrm{SE} \\
\text { of trend }\end{array}$ & $r^{2}$ & NMBF & RMSE \\
\hline Sulfate annual & $\begin{array}{l}\text { observed } \\
\text { model }\end{array}$ & $\begin{array}{l}-1.23 \\
-1.15\end{array}$ & $\begin{array}{l}0.466 \\
0.424\end{array}$ & $\begin{array}{l}-68 \% \\
-78 \%\end{array}$ & $\begin{array}{l}-0.048 \\
-0.044\end{array}$ & $\begin{array}{l}-0.053 \\
-0.048\end{array}$ & $\begin{array}{l}-0.043 \\
-0.040\end{array}$ & 0.434 & -0.384 & 0.334 \\
\hline Sulfate DJF & $\begin{array}{l}\text { observed } \\
\text { model }\end{array}$ & $\begin{array}{l}-1.67 \\
-0.53\end{array}$ & $\begin{array}{l}0.65 \\
0.20\end{array}$ & $\begin{array}{l}-73 \% \\
-75 \%\end{array}$ & $\begin{array}{l}-0.064 \\
-0.020\end{array}$ & $\begin{array}{l}-0.073 \\
-0.023\end{array}$ & $\begin{array}{l}-0.055 \\
-0.017\end{array}$ & 0.385 & -2.19 & 0.978 \\
\hline Sulfate JJA & $\begin{array}{l}\text { observed } \\
\text { model }\end{array}$ & $\begin{array}{l}-1.39 \\
-3.35\end{array}$ & $\begin{array}{l}0.57 \\
1.34\end{array}$ & $\begin{array}{l}-70 \% \\
-86 \%\end{array}$ & $\begin{array}{l}-0.056 \\
-0.138\end{array}$ & $\begin{array}{l}-0.064 \\
-0.152\end{array}$ & $\begin{array}{l}-0.048 \\
-0.124\end{array}$ & 0.434 & 0.694 & 1.17 \\
\hline
\end{tabular}

observed SPM mass concentrations could indicate that an additional emission source or process for generating supermicron aerosol mass is missing from the model, particularly in the 1980s and early 1990s when the model bias is largest.

Figure 8c shows that the larger observed trend in European annual mean SPM mass over the period 1978-1998 of $-1.19 \pm 0.22 \mu \mathrm{g} \mathrm{m}^{-3} \mathrm{yr}^{-1}$ is substantially different to the simulated trend of $-0.26 \pm 0.12 \mu \mathrm{g} \mathrm{m}^{-3} \mathrm{yr}^{-1}$ (Table 3). Figure 10a shows that the observed trends in SPM mass concentrations are underpredicted at all the measurement locations, with little seasonal differences. The calculated trends in simulated and observed SPM values are considered to be different as they are outside the range of \pm two standard errors of each trend line (Table 3 ).

Figure $8 \mathrm{~d}$ and e compare simulated and observed annual mean $\mathrm{PM}_{10}$ mass concentrations over Europe in 2000 and 2009. A slight reduction in $\mathrm{PM}_{10}$ mass concentrations of 8 $9 \%$ was both observed and simulated over this period (Table 3), with the largest reductions occurring over central and north-eastern continental Europe. 
a) 1980

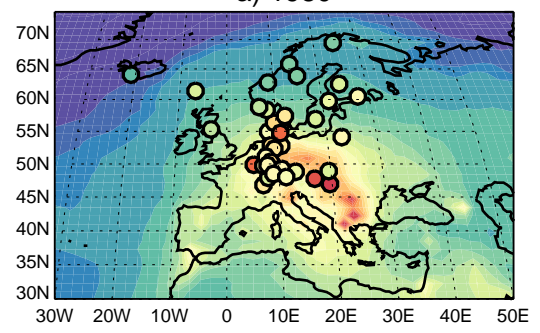

c) 2000

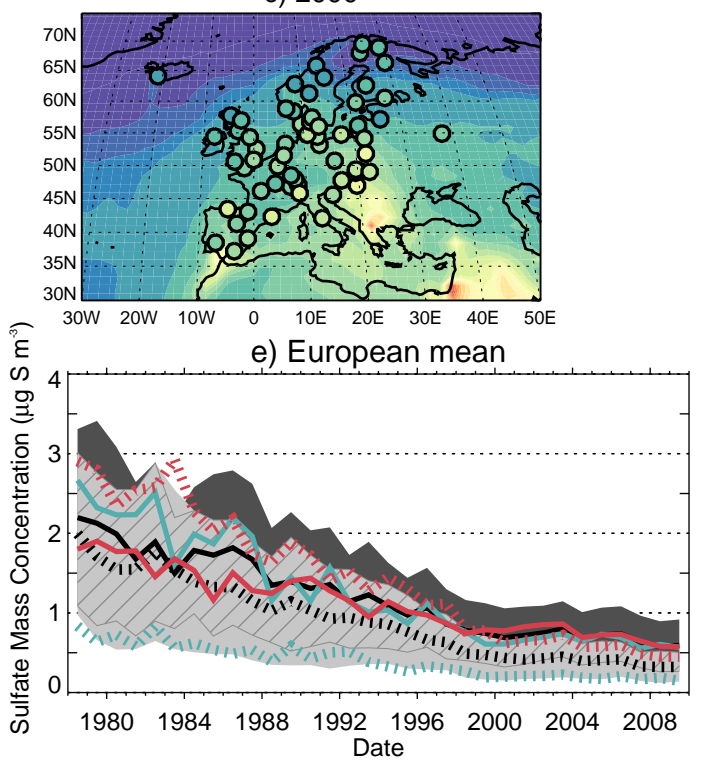

b) 1990

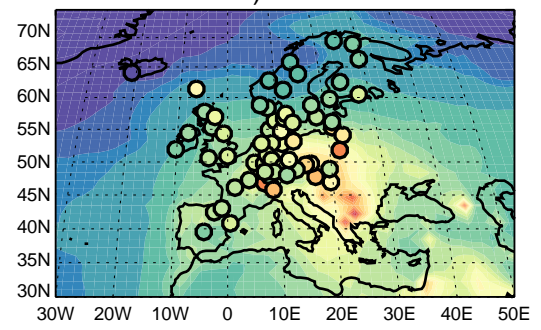

d) 2009

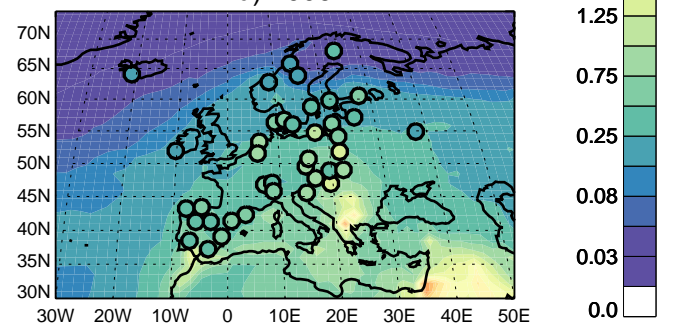

Observations

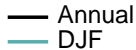

- DJF

- JJA

Model

.... DJF

.... JJA

Error Polygons

+/- Model S.D.

Figure 5. Annual mean sulfate aerosol mass concentrations $\left(\mu \mathrm{g} \mathrm{m}^{-3}\right)$ from the lowest model level with observations overplotted in circles for (a) 1980, (b) 1990, (c) 2000 and (d) 2009. (e) Time series of annual and seasonal mean observed (solid lines) and modelled (dashed lines) sulfate concentrations averaged across all measurement locations for each particular year. Shaded areas show \pm 1 standard deviation of the modelled (light grey) and observed (dark grey) annual mean values, with the hatching identifying areas of overlap.

The model generally underestimates observed $\mathrm{PM}_{10}$ mass concentrations (NMBF of 0 to -1 ) for the majority of European regions and across most of the evaluated years (Fig. 9b). An exception occurs across northern and north-western Europe in wintertime where the model overpredicts concentrations (NMBF of $0-2$ ). This is potentially caused by an overestimation of sea salt aerosol (as also seen in studies by Mann et al., 2010, 2012), so it mostly affects coastal locations. Overall, the model simulates European $\mathrm{PM}_{10}$ mass concentrations between 1997 and 2009 within a factor of 2 and is much improved when compared to the simulation of total SPM between 1978 and 1998.

The temporal changes in $\mathrm{PM}_{10}$ mass concentrations (Fig. 8f) highlight the smaller difference between simulated and observed $\mathrm{PM}_{10}$ across Europe compared to SPM. The linear trends for observed $\left(-0.27 \pm 0.24 \mu \mathrm{g} \mathrm{m}^{-3} \mathrm{yr}^{-1}\right)$ and simulated $\left(-0.14 \pm 0.16 \mu \mathrm{g} \mathrm{m}^{-3} \mathrm{yr}^{-1}\right) \mathrm{PM}_{10}$ mass concentrations over the period 1997-2009 are similar (gradients within twice the standard error of each other) (Table 3). However, Fig. 10b shows that the magnitude of the observed downward trends is slightly underpredicted at the majority of measurement locations, with little difference between summer and winter.

The model underpredicts SPM mass concentrations by up to $20 \mu \mathrm{g} \mathrm{m}^{-3}$ in the $1980 \mathrm{~s}$ and $\mathrm{PM}_{10}$ by less than $5 \mu \mathrm{g} \mathrm{m}{ }^{-3}$ in the 2000s. This larger underprediction in the 1990s could be due to errors in the measurement of SPM, as most of these observations are not well documented (Tørseth et al., 2012) and may have substantial uncertainty. We compared SPM and PM $_{10}$ observations during a period when both variables were observed at six monitoring sites in Spain, and found SPM was greater than $\mathrm{PM}_{10}$ by $6-17 \mu \mathrm{g} \mathrm{m}^{-3}$. Taking this into account, along with the better model agreement for $\mathrm{PM}_{10}$ mass, indicates that coarse-sized particles $(D>10 \mu \mathrm{m})$ are under-represented by the model. Potential anthropogenic sources of coarse particles that are not represented in the model include road traffic dust and construction sources.

Underprediction of aerosol mass could be due to underestimation of aerosol processes, as well as missing aerosol sources from the model. The model does not include nitrate 
Table 3. Statistical summary of modelled and observed annual and seasonal (DJF and JJA) mean SPM concentrations at all long-term (> 20 years of data) measurement sites (34 sites) between 1978 and 1998. A similar comparison is presented for PM 10 mass concentrations at all long-term (> 10 years of data) measurement sites (16 sites) between 1997 and 2009. Absolute and relative (\%) changes in concentrations are calculated as the difference between the mean of the initial 5 years of data minus the mean of the last 5 years of data. Trends that are above or below the value of twice of the standard error of the trend (95\% confidence) are highlighted in bold.

\begin{tabular}{|c|c|c|c|c|c|c|c|c|c|c|}
\hline Component & Type & $\begin{array}{r}\text { Absolute change } \\
\text { in concentration } \\
\left(\mu \mathrm{g} \mathrm{m}^{-3}\right)\end{array}$ & $\begin{array}{l}\text { Standard deviation } \\
\text { of mean value }\end{array}$ & $\begin{array}{l}\% \text { Change in } \\
\text { concentration }\end{array}$ & $\begin{array}{r}\text { calculated } \\
\text { linear trend } \\
\left(\mu \mathrm{g} \mathrm{m}^{-3} \mathrm{yr}^{-1}\right)\end{array}$ & $\begin{array}{l}-2 * \mathrm{SE} \\
\text { of trend }\end{array}$ & $\begin{array}{l}+2 * \mathrm{SE} \\
\text { of trend }\end{array}$ & $r^{2}$ & NMBF & RMSE \\
\hline SPM Annual & $\begin{array}{l}\text { observed } \\
\text { model }\end{array}$ & $\begin{array}{r}-18.32 \\
-4.11\end{array}$ & $\begin{array}{l}7.96 \\
2.36\end{array}$ & $\begin{array}{l}-42 \% \\
-20 \%\end{array}$ & $\begin{array}{l}-1.19 \\
-0.26\end{array}$ & $\begin{array}{l}-1.41 \\
-0.39\end{array}$ & $\begin{array}{l}-0.97 \\
-0.14\end{array}$ & 0.104 & -0.88 & 18.04 \\
\hline SPM DJF & $\begin{array}{l}\text { observed } \\
\text { model }\end{array}$ & $\begin{array}{r}-24.50 \\
-3.95\end{array}$ & $\begin{array}{r}10.81 \\
3.82\end{array}$ & $\begin{array}{l}-51 \% \\
-19 \%\end{array}$ & $\begin{array}{l}-1.52 \\
-0.27\end{array}$ & $\begin{array}{l}-1.91 \\
-0.52\end{array}$ & $\begin{array}{l}-1.13 \\
-0.02\end{array}$ & 0.044 & -0.852 & 19.39 \\
\hline SPM JJA & $\begin{array}{l}\text { observed } \\
\text { model }\end{array}$ & $\begin{array}{r}-14.80 \\
-5.06\end{array}$ & $\begin{array}{l}7.74 \\
2.94\end{array}$ & $\begin{array}{l}-35 \% \\
-23 \%\end{array}$ & $\begin{array}{l}-1.04 \\
-0.38\end{array}$ & $\begin{array}{l}-1.36 \\
-0.51\end{array}$ & $\begin{array}{l}-0.72 \\
-0.25\end{array}$ & 0.354 & -0.796 & 16.41 \\
\hline $\mathrm{PM}_{10}$ Annual & $\begin{array}{l}\text { observed } \\
\text { model }\end{array}$ & $\begin{array}{l}-1.50 \\
-1.08\end{array}$ & $\begin{array}{l}1.84 \\
1.16\end{array}$ & $\begin{array}{l}-9 \% \\
-8 \%\end{array}$ & $\begin{array}{l}-0.27 \\
-0.14\end{array}$ & $\begin{array}{l}-0.50 \\
-0.30\end{array}$ & $\begin{array}{r}-0.03 \\
0.02\end{array}$ & 0.037 & -0.221 & 3.35 \\
\hline $\mathrm{PM}_{10} \mathrm{DJF}$ & $\begin{array}{l}\text { observed } \\
\text { model }\end{array}$ & $\begin{array}{l}-1.53 \\
-2.40\end{array}$ & $\begin{array}{l}2.35 \\
3.04\end{array}$ & $\begin{array}{r}-9 \% \\
-15 \%\end{array}$ & $\begin{array}{l}-0.29 \\
-0.29\end{array}$ & $\begin{array}{l}-0.61 \\
-0.73\end{array}$ & $\begin{array}{l}0.03 \\
0.14\end{array}$ & 0.023 & -0.12 & 4.01 \\
\hline $\mathrm{PM}_{10} \mathrm{JJA}$ & $\begin{array}{l}\text { observed } \\
\text { model }\end{array}$ & $\begin{array}{l}0.19 \\
3.12\end{array}$ & $\begin{array}{l}1.87 \\
2.75\end{array}$ & $\begin{array}{r}1 \% \\
30 \%\end{array}$ & $\begin{array}{r}-0.02 \\
0.32\end{array}$ & $\begin{array}{l}-0.31 \\
-0.06\end{array}$ & $\begin{array}{l}0.27 \\
0.70\end{array}$ & 0.295 & -0.339 & 4.66 \\
\hline
\end{tabular}

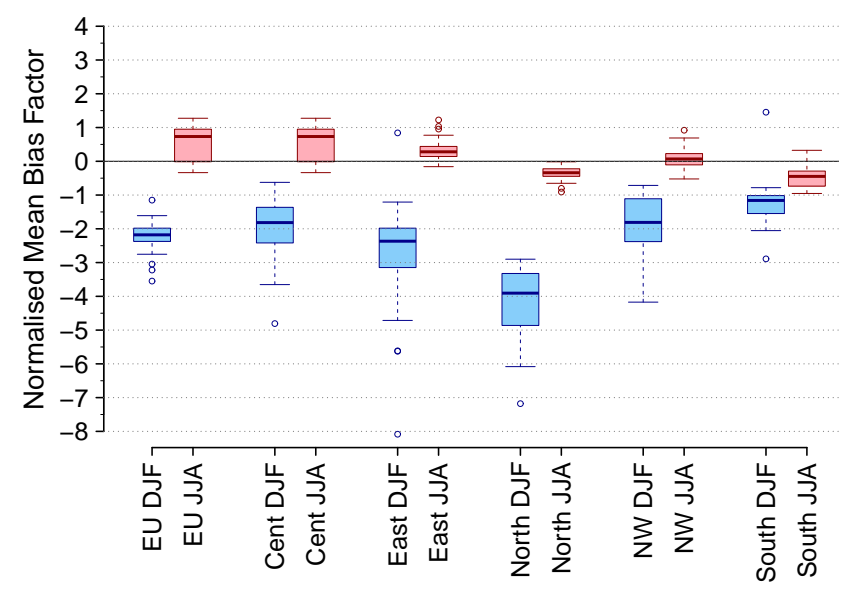

Figure 6. European and sub-regional normalised mean bias factors for summertime (red) and wintertime (blue) sulfate aerosol mass concentrations across all the years that data were available. The solid line shows the median value, the boxes show the 25 th and 75th percentile values with the error bars showing the maximum and minimum values and the circles representing outliers (values $>1.5 \times$ interquartile range).

aerosol which could account for $1-3 \mu \mathrm{g} \mathrm{m}^{-3}$ of aerosol mass over Europe (Fagerli and Aas, 2008; Bellouin et al., 2011; Pozzer et al., 2012). This could be particularly important in reducing the model bias in winter and over northern and north-western Europe where nitrate concentrations are anticipated to be largest. The reductions in $\mathrm{SO}_{2}$ emissions and increase in $\mathrm{NH}_{3}$ emissions across Europe over the last 30 years (Fig. 2) could have important impacts on aerosol composi-

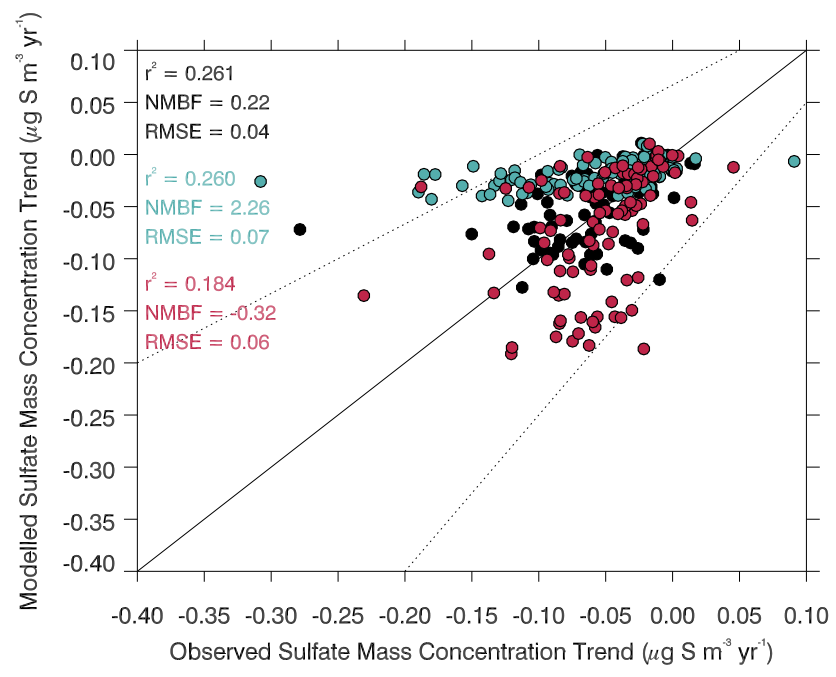

Figure 7. Annual (black), summertime (red) and wintertime (blue) trends in modelled and observed sulfate aerosol mass concentrations ( $\mu \mathrm{g} \mathrm{S} \mathrm{m}^{-3} \mathrm{yr}^{-1}$ ) at each individual monitoring location over their operational period between 1978 and 2009.

tion (Fagerli and Aas, 2008). In historical periods with high $\mathrm{SO}_{2}$ emissions, sulfate aerosol dominates and nitrate concentrations are likely to be small. In the recent past and in the future, declines in $\mathrm{SO}_{2}$ and sulfate aerosol mass, coupled with an increase in $\mathrm{NH}_{3}$ emissions, may lead to increased nitrate aerosol concentrations. Inclusion of nitrate aerosol would reduce the model bias in $\mathrm{PM}_{10}$ concentrations over more recent years but would have a smaller fractional impact in the 1980s-1990s due to the dominance of sulfate concentrations. 
a) 1980

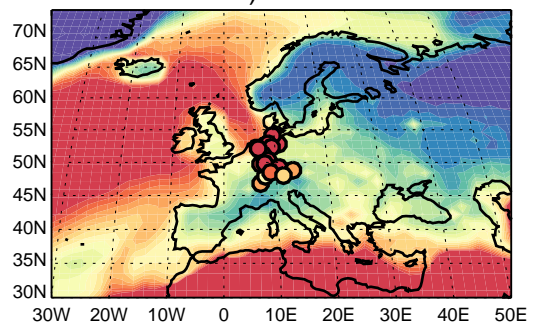

b) 1990

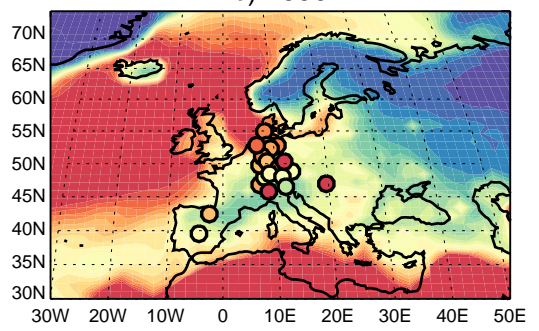

c) SPM European Mean

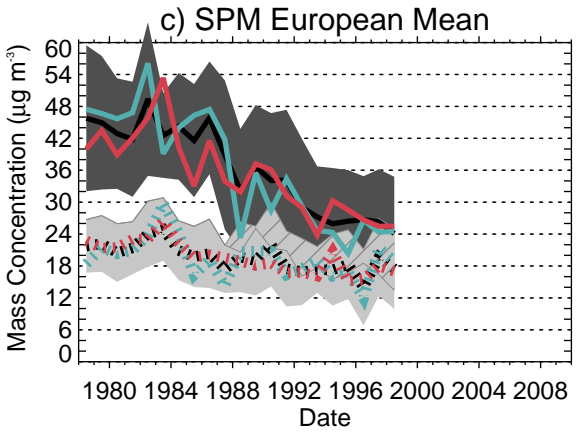

d) 2000

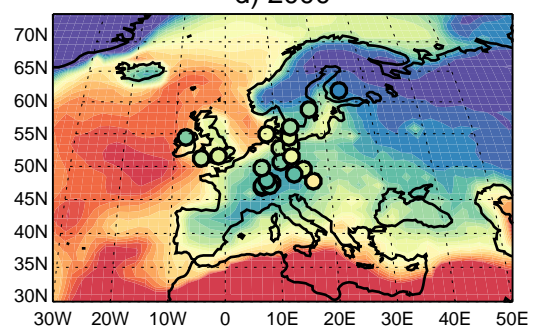

e) 2009
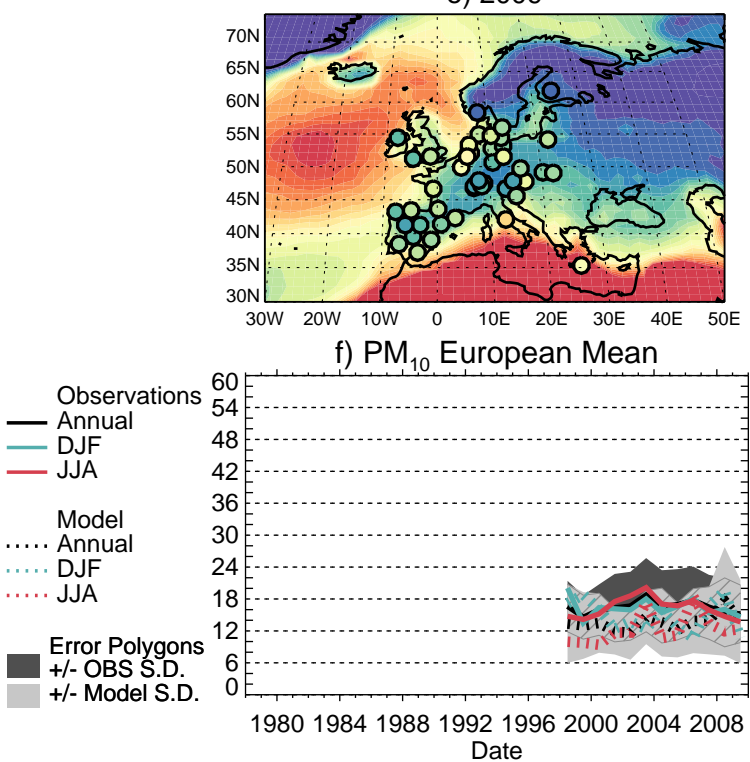

f) $\mathrm{PM}_{10}$ European Mean

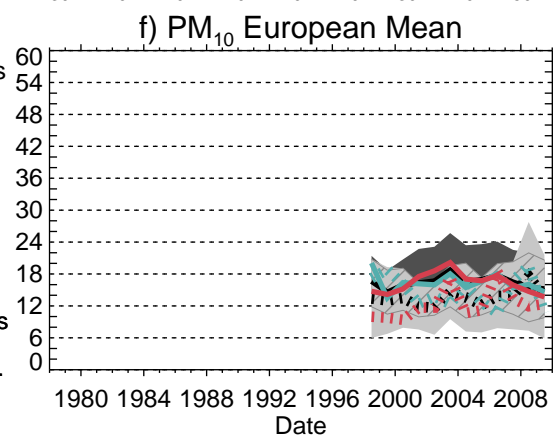

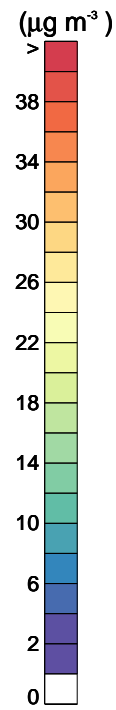

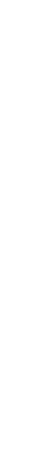

Figure 8. Annual mean SPM mass concentrations $\left(\mu \mathrm{g} \mathrm{m}^{-3}\right.$ ) from the lowest model level with observations overplotted in circles for (a) 1980 and (b) 1990. (d) and (e) are the same as (a) and (b) but for PM 10 mass concentrations in 2000 and 2009. A time series of annual and seasonal mean observed (solid lines) and modelled (dashed lines) (c) SPM and (f) PM $_{10}$ concentrations averaged across all measurement locations for each particular year. Shaded areas show \pm 1 standard deviation of the modelled (light grey) and observed (dark grey) annual mean values, with the hatching identifying areas of overlap.

The model also does not include primary biological aerosol sources, which may contribute $1-2 \mu \mathrm{g} \mathrm{m}^{-3}$ to $\mathrm{PM}_{10}$ mass over Europe (Heald and Spracklen, 2009); the contribution to $D>10 \mu \mathrm{m}$ is not known.

Uncertainty in aerosol precursor emissions will also contribute to the model-observation discrepancy. In particular, domestic wood burning and wildfires could contribute up to $50 \%$ of OC locally over Europe and may be underestimated in emission data sets (Hodzic et al., 2007; Langmann et al., 2008; Manders et al., 2012). The calculation of SOA is also a large uncertainty, particularly the proportions from anthropogenic and biogenic sources. Global aerosol models typically underpredict the amount of organic aerosols in the atmosphere (Tsigaridis et al., 2014), particularly from anthropogenic sources (Volkamer et al., 2006; Farina et al., 2010; Spracklen et al., 2011). Anthropogenic sources (or anthropogenically modified biogenic sources) that are not accounted for here may contribute up to $3 \mu \mathrm{g} \mathrm{m}^{-3}$ of SOA over Europe (Spracklen et al., 2011).
Nevertheless, even using the upper estimates of some of these potential missing sources, there still appears to be a model underprediction of total aerosol mass particularly during the early period (1980-1990), suggesting that additional sources or processes are missing within the model or that removal processes are overestimated.

\subsubsection{Aerosol size distribution}

Figure 11a-c compare simulated and observed annual mean surface aerosol number concentrations averaged over the period 2008-2009 for particles with dry diameter greater than 30,50 and $100 \mathrm{~nm}$. The model underestimates the observed aerosol number concentrations for all size fractions, with a slightly larger model bias for larger size particles (N100 $\mathrm{NMBF}=-0.96 ; \mathrm{N} 50 \mathrm{NMBF}=-0.65$; and N30 NMBF $=-0.85$ ). The model substantially underestimates aerosol number concentrations over all size fractions at the high latitude Arctic monitoring locations of Pallas and Zeppelin. In addition, simulated aerosol number concentrations are under- 


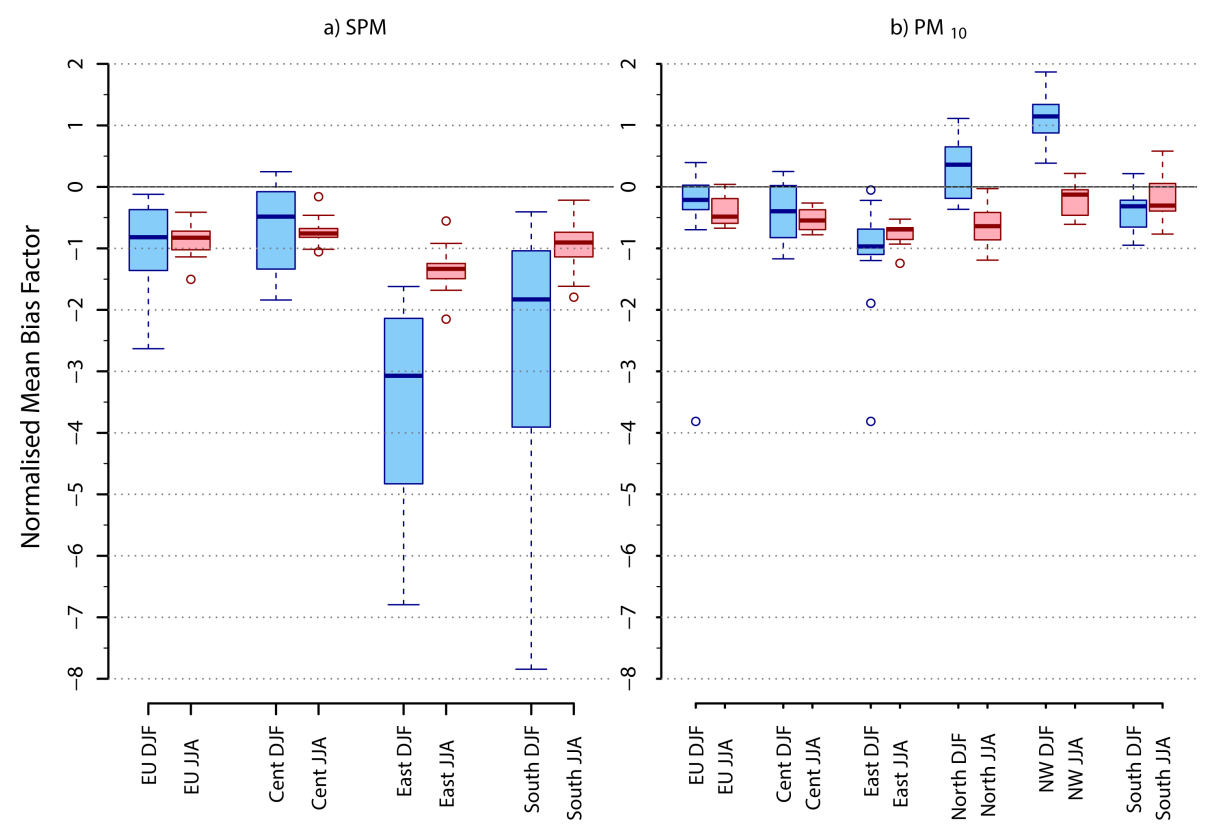

Figure 9. European and sub-regional normalised mean bias factors for summertime (red) and wintertime (blue) (a) $\mathrm{SPM}_{\text {and }}$ (b) PM 10 mass concentrations across all the years that data were available. The solid line shows the median value, the boxes show the 25 th and 75 th percentile values with the error bars showing the maximum and minimum values and the circles representing outliers (values $>1.5 \times$ interquartile range).
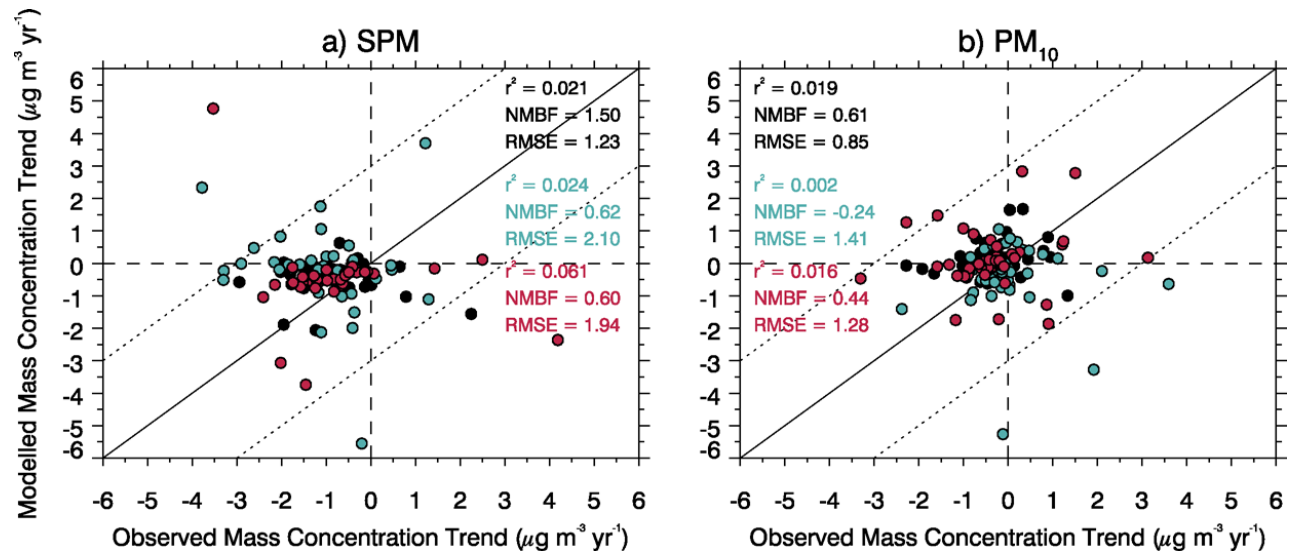

Figure 10. Calculated annual (black), summertime (red) and wintertime (blue) linear trends in modelled and observed (a) $\mathrm{SPM}_{\text {and }}$ (b) $\mathrm{PM}_{10}$ mass concentrations $\left(\mu \mathrm{g} \mathrm{S} \mathrm{m}^{-3} \mathrm{yr}^{-1}\right.$ ) at each individual monitoring location over their operational period between 1978 and 2002 for SPM and between 1996 and 2009 for $\mathrm{PM}_{10}$.

estimated to a larger extent at the more polluted, central European monitoring sites of Ispra, Preila, Bösel and K-Puszta.

The model is able to reproduce the observed aerosol number concentrations within a factor of 2 at the majority of European monitoring locations, which is in agreement with the recent intercomparison and evaluation of global aerosol microphysical models (Mann et al., 2014). In addition, Mann et al. (2014) also found that all of the evaluated models underestimated aerosol number concentrations in the Arctic.
This suggests that N50 concentrations (a proxy for CCN concentrations) are slightly underpredicted by the model in the present day but have declined across Europe (Fig. 4b) by $50 \%$ since the 1970 s, with a large potential impact on the European radiative balance. However, over the more recent period of 2001-2010 no discernible trend was found in aerosol number concentration by Asmi et al. (2013) across three central European monitoring sites. 

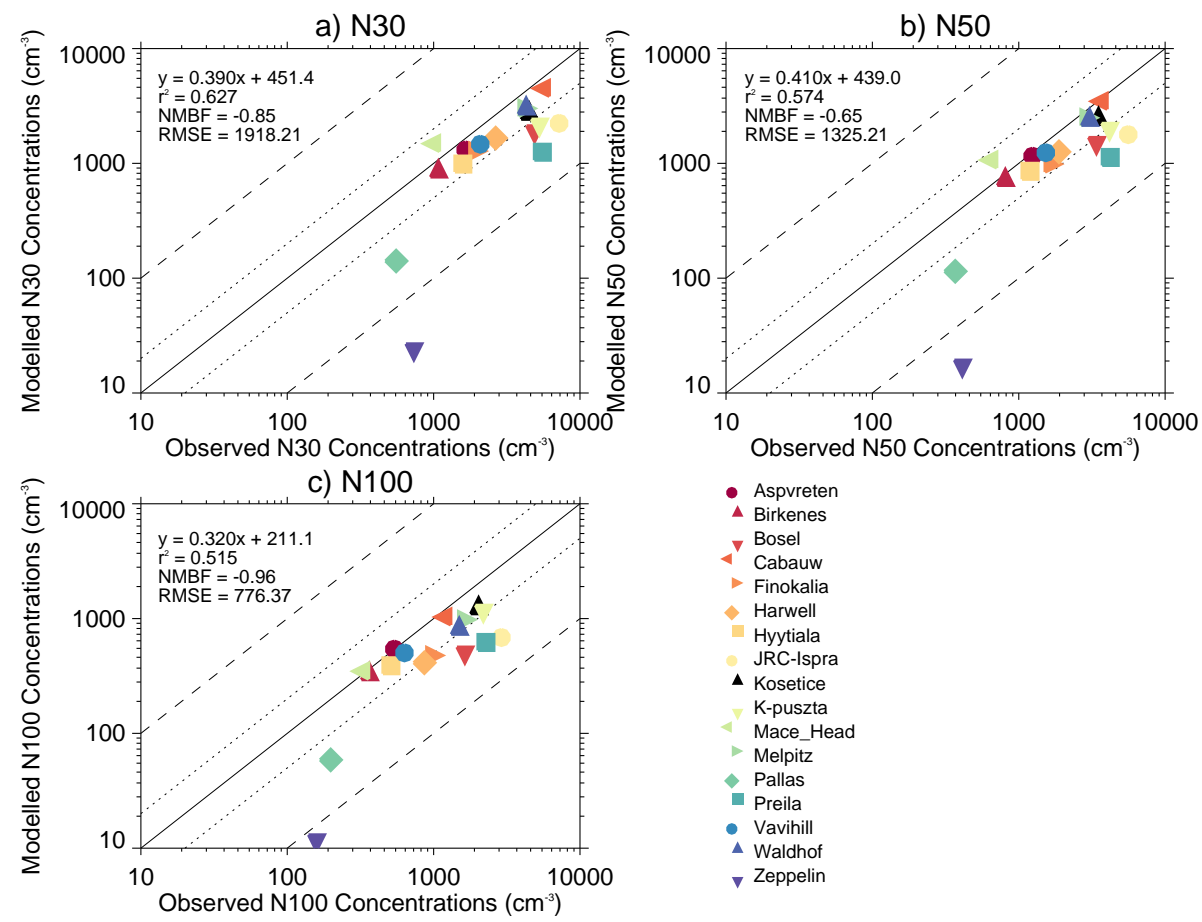

Figure 11. Annual mean observed vs. simulated aerosol number concentrations for (a) N30 (particles greater than $30 \mathrm{~nm}$ diameter), (b) N50 $(>50 \mathrm{~nm})$ and (c) N100 (>100 nm) at monitoring sites across Europe.

\subsubsection{Aerosol optical depth}

Figure 12a, $\mathrm{b}$ compare simulated and observed annual mean AOD at $440 \mathrm{~nm}$ in 2000 and 2009. The largest simulated and observed AOD occurs over eastern and south-eastern Europe. The model is relatively unbiased against annual mean AOD $(\mathrm{NMBF}=-0.013)$. The model captures the observed seasonal cycle in European AOD with the highest AOD in the summer and lowest in the winter but overestimates wintertime $\mathrm{AOD}(\mathrm{NMBF}=0.258)$ and underestimates summertime AOD (NMBF $=-0.167)$ (Table 4). These seasonal biases are of opposite sign to those for sulfate and $\mathrm{PM}_{10}$. However, we note that simulation of AOD requires information on aerosol optics, aerosol size distribution and atmospheric humidity, meaning it is difficult to relate to comparisons of surface aerosol mass.

Observed and simulated AOD has declined over the period 2000-2009 (Fig. 12c). Table 4 shows that at the three monitoring locations with the longest data records (9-10 years), simulated and observed AOD has declined by a similar magnitude (11-14\%) but AOD is underestimated by the model (NMBF $=-0.296)$. The observed AOD trend at the three long-term sites in the period 20002009 is $-0.007 \pm 0.004 \mathrm{yr}^{-1}$ and is similar to that modelled of $-0.006 \pm 0.0008 \mathrm{yr}^{-1}$ (Table 4). The trend in observed wintertime AOD $\left(-0.006 \pm 0.002 \mathrm{yr}^{-1}\right)$ is well captured by the model $\left(-0.007 \pm 0.002 \mathrm{yr}^{-1}\right)$. The larger observed summertime trend of $-0.014 \pm 0.003 \mathrm{yr}^{-1}$ is under- estimated $\left(-0.005 \pm 0.002 \mathrm{yr}^{-1}\right)$. The ability of the model to reproduce the decline in $\mathrm{AOD}$ is similar for sulfate and $\mathrm{PM}_{10}$.

\subsubsection{Surface solar radiation}

Figure 13 shows simulated and observed annual mean all-sky SSR anomalies across Europe between 1960 and 2009, relative to a 1980-2000 mean. The long-term mean was based on the period 1980-2000, considered to be the period with the most reliable observations. Evaluation of SSR has been split into three distinct time periods (1960-1974, 1975-1989 and 1990-2009) based on the changes in the observed all-sky SSR values (Table 5). The observed SSR anomaly is generally positive and relatively constant in the period 1960-1974. There is a decrease in observed SSR from 1975 until the late 1980s, after which a strong increase in SSR is observed from 1990 to 2009.

Between 1990 and 2009 both the observed and simulated European SSR increases by 5.8 and $4.0 \mathrm{~W} \mathrm{~m}^{-2}$ respectively with similar positive linear trends $\left(0.37-0.32 \mathrm{~W} \mathrm{~m}^{-2} \mathrm{yr}^{-1}\right.$; Table 5). The highest spatial correlation $\left(r^{2}=0.90\right)$ between modelled and observed SSR values occurs in the period 1990-2009, whereas the bias $(\mathrm{NMBF}=0.04)$ and error (RMSE $=8.0$ ) in SSR are similar to that in 1975-1989. An evaluation of seasonal mean modelled and observed SSR also showed small differences in the NMBF over each season for all time periods, although RMSE is larger and the spatial correlation is smaller in summer. The positive SSR trend 
Table 4. Statistical summary of modelled and observed annual and seasonal (DJF and JJA) mean AOD at all long-term ( $>7$ years of data) measurement sites (13 sites) between 2000 and 2009. A similar comparison is presented at the three measurement locations that contain annual mean observations throughout every year between 2000 and 2009 (AOD, three sites). Absolute and relative (\%) changes in concentrations are calculated as the difference between the mean of the initial 5 years of data minus the mean of the last 5 years of data. Trends that are above or below the value of twice of the standard error of the trend (95\% confidence) are highlighted in bold.

\begin{tabular}{|c|c|c|c|c|c|c|c|c|c|c|}
\hline Component & Type & $\begin{array}{r}\text { Absolute } \\
\text { change } \\
\text { in AOD }\end{array}$ & $\begin{array}{r}\text { Standard deviation } \\
\text { of mean value }\end{array}$ & $\begin{array}{r}\% \text { Change } \\
\text { in AOD }\end{array}$ & $\begin{array}{r}\text { Calculated } \\
\text { linear trend } \\
\left(\mathrm{AOD} \mathrm{yr}^{-1}\right)\end{array}$ & $\begin{array}{l}-2 * \mathrm{SE} \\
\text { of trend }\end{array}$ & $\begin{array}{l}+2 * \mathrm{SE} \\
\text { of trend }\end{array}$ & $r^{2}$ & NMBF & RMSE \\
\hline AOD & $\begin{array}{l}\text { observed } \\
\text { model }\end{array}$ & $\begin{array}{r}-0.03 \\
-0.006\end{array}$ & $\begin{array}{l}0.022 \\
0.014\end{array}$ & $\begin{array}{r}-12 \% \\
-2 \%\end{array}$ & $\begin{array}{r}-0.0061 \\
0.00005\end{array}$ & $\begin{array}{l}-0.009 \\
-0.003\end{array}$ & $\begin{array}{r}-0.003 \\
0.003\end{array}$ & 0.031 & -0.013 & 0.026 \\
\hline AOD 3 Sites & $\begin{array}{l}\text { observed } \\
\text { model }\end{array}$ & $\begin{array}{l}-0.03 \\
-0.03\end{array}$ & $\begin{array}{l}0.037 \\
0.019\end{array}$ & $\begin{array}{l}-11 \% \\
-14 \%\end{array}$ & $\begin{array}{l}-0.007 \\
-0.006\end{array}$ & $\begin{array}{l}-0.014 \\
-0.007\end{array}$ & $\begin{array}{l}-0.001 \\
-0.004\end{array}$ & 0.011 & -0.296 & 0.066 \\
\hline AOD DJF & $\begin{array}{l}\text { observed } \\
\text { model }\end{array}$ & $\begin{array}{l}-0.024 \\
-0.040\end{array}$ & $\begin{array}{l}0.026 \\
0.027\end{array}$ & $\begin{array}{l}-13 \% \\
-16 \%\end{array}$ & $\begin{array}{l}-0.0063 \\
-0.0074\end{array}$ & $\begin{array}{l}-0.010 \\
-0.011\end{array}$ & $\begin{array}{l}-0.002 \\
-0.004\end{array}$ & 0.024 & 0.258 & 0.050 \\
\hline AOD JJA & $\begin{array}{l}\text { observed } \\
\text { model }\end{array}$ & $\begin{array}{l}-0.072 \\
-0.030\end{array}$ & $\begin{array}{l}0.047 \\
0.021\end{array}$ & $\begin{array}{l}-23 \% \\
-12 \%\end{array}$ & $\begin{array}{l}-0.014 \\
-0.005\end{array}$ & $\begin{array}{l}-0.019 \\
-0.008\end{array}$ & $\begin{array}{l}-0.008 \\
-0.002\end{array}$ & 0.039 & -0.167 & 0.053 \\
\hline
\end{tabular}

a) 2000

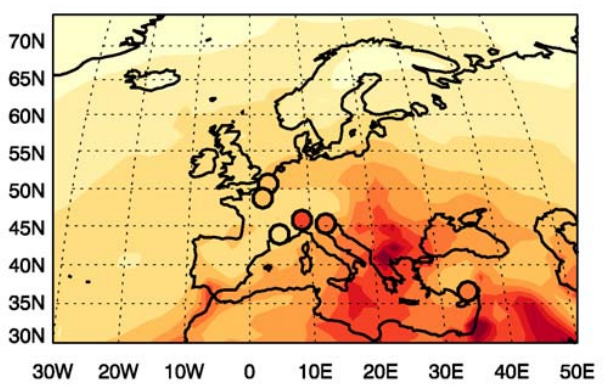

c)

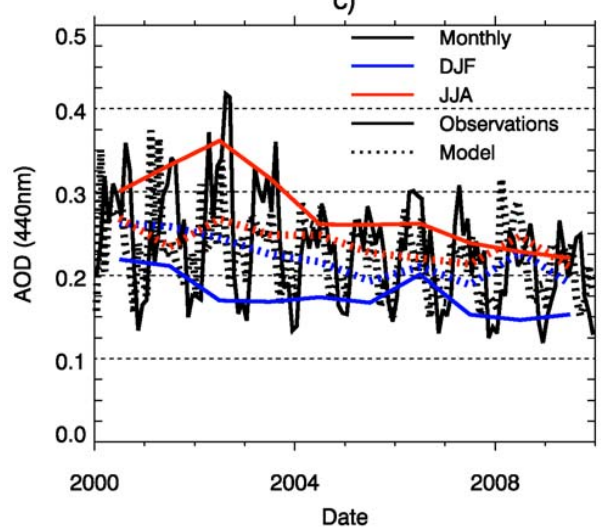

b) 2009

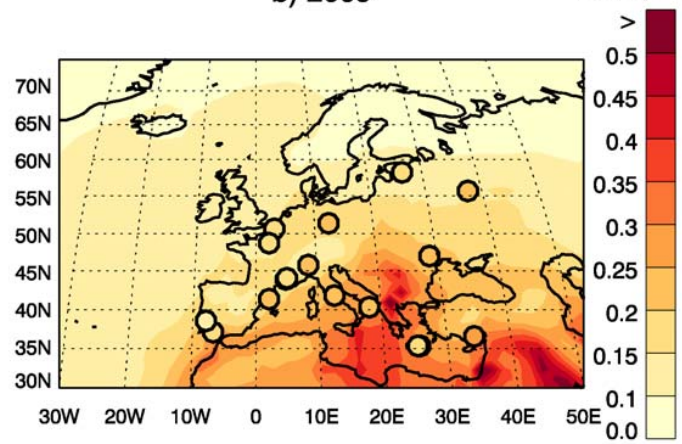

d)

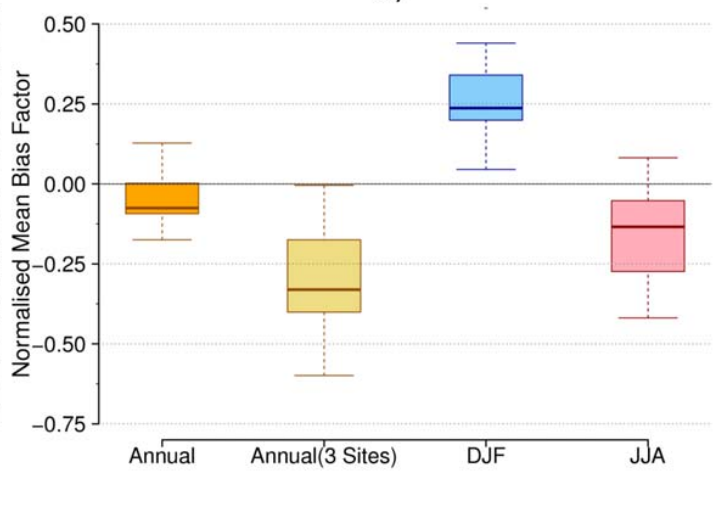

Figure 12. Annual mean AOD at $440 \mathrm{~nm}$ with observations from the AERONET sites overplotted for (a) 2000 and (b) 2009. (c) Time series of monthly and seasonal mean observed (solid lines) and modelled (dashed lines) AOD at 440 nm averaged across all measurement locations. (d) European NMBFs of AOD for annual (orange), summertime (red) and wintertime (blue) across all the years and sites that data were available. The annual NMBF for the three sites with the longest continuous record ( $>9$ years) is shown in yellow. 
Table 5. Statistical summary of simulated and observed annual mean SSR for three different time periods (1960-1974, 1975-1989 and 1990-2009) at the 20 measurement sites across Europe which have a continuous 50-year data record. Absolute and relative (\%) changes in SSR are calculated as the difference between the mean of the initial 5 years of data minus the mean of the last 5 years of data for the time period considered. Trends that are above or below the value of twice of the standard error of the trend ( $95 \%$ confidence) are highlighted in bold.

\begin{tabular}{lrrrrrrrrrrr}
\hline Type & Time period & $\begin{array}{r}\text { Absolute } \\
\text { change in } \\
\text { SSR }\left(\mathrm{W} \mathrm{m}^{-2}\right)\end{array}$ & $\begin{array}{r}\text { Standard deviation } \\
\text { of mean value }\end{array}$ & $\begin{array}{r}\text { \% Change } \\
\text { in SSR }\end{array}$ & $\begin{array}{r}\text { Calculated } \\
\text { linear trend } \\
\left(\mathrm{W} \mathrm{m}^{-2} \mathrm{yr}^{-1}\right)\end{array}$ & $\begin{array}{r}-2 * \mathrm{SE} \\
\text { of trend }\end{array}$ & $\begin{array}{c}+2 * \mathrm{SE} \\
\text { of trend }\end{array}$ & $r^{2}$ & NMBF & RMSE \\
\hline observed & & -0.79 & & 2.40 & -1 & -0.011 & -0.309 & 0.286 & 0.838 & 0.002 & 7.72 \\
model + ARE & $1960-1974$ & -1.67 & 1.89 & -1 & -0.088 & -0.317 & 0.141 & 0.748 & 0.045 & 11.04 \\
model - ARE & & -0.20 & 2.12 & -0.2 & 0.069 & -0.237 & 0.376 & 0.748 \\
\hline observed & $1975-1989$ & -2.24 & 3.42 & -2 & -0.259 & -0.658 & 0.140 & 0.803 & 0.029 & 8.43 \\
model + ARE & 3.12 & 3.06 & 3 & 0.304 & -0.036 & 0.643 & 0.757 & 0.063 & 11.84 \\
model - ARE & 1.89 & 3.50 & 1.6 & 0.187 & -0.191 & 0.564 & 0.757 \\
\hline observed & & 5.78 & 3.47 & 5 & 0.369 & 0.153 & 0.584 & 0.896 & 0.043 & 8.00 \\
model + ARE & $1990-2009$ & 3.98 & 3.04 & 3 & 0.316 & 0.125 & 0.507 & 0.896 \\
model - ARE & & 0.27 & 2.92 & 0.2 & 0.09 & -0.185 & 0.366 & 0.828 & 0.053 & 10.23 \\
\hline
\end{tabular}

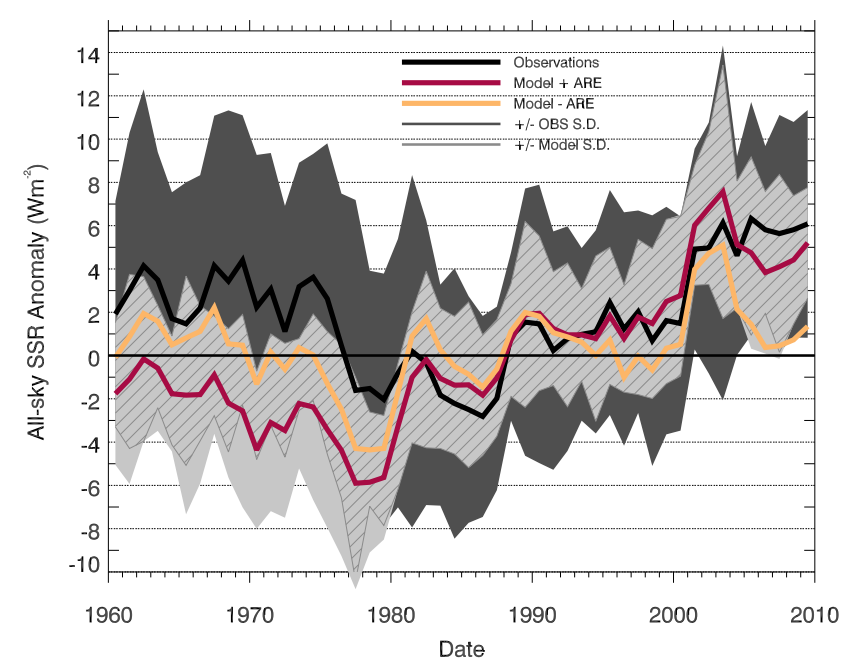

Figure 13. Observed (black line) and simulated (red line) European annual mean all-sky SSR anomalies $\left(\mathrm{Wm}^{-2}\right)$ relative to a 1980 2000 average. Simulated all-sky SSR not including aerosol radiative effects (ARE) is also shown (orange line). Values are calculated as the average across all measurement locations within Europe (see Fig. 1). The standard deviation of the annual mean for each year is shown by the shaded areas of dark grey for the observations and light grey for the model with the hatching representing where the areas overlap.

(brightening) observed between the late 1980s and 2009 is reproduced by the model, but simulated brightening begins several years earlier than observed. The positive trend in SSR anomaly across Europe from the mid-1980s to present day corresponds with the observed and simulated decrease in aerosol concentrations. Figure 13 also shows the modelled all-sky SSR anomalies without aerosol radiative effects (ARE). Without ARE the simulated trend in SSR is underestimated $\left(0.09 \pm 0.14 \mathrm{~W} \mathrm{~m}^{-2} \mathrm{yr}^{-1}\right)$, suggesting that changes in aerosol concentrations are a dominant driver of SSR trends during this period. The simulated positive trend in SSR including ARE presented here is in agreement with other studies over this period (Wild, 2009; Allen et al., 2013; SanchezLorenzo et al., 2013; Chiacchio et al., 2015).

In the period 1975-1989, both the modelled and observed SSR anomalies are generally negative, which coincides with the maximum anthropogenic emissions and atmospheric aerosol loading. Over this period the observed SSR decreases by an average of $2.2 \mathrm{~W} \mathrm{~m}^{-2}$, whilst simulated SSR increases by $3.1 \mathrm{~W} \mathrm{~m}^{-2}$ (Table 5). A similar discrepancy in sign and magnitude is also apparent in the linear trends of the model $\left(0.30 \pm 0.17 \mathrm{~W} \mathrm{~m}^{-2} \mathrm{yr}^{-1}\right)$ and observations $\left(-0.26 \pm 0.20 \mathrm{~W} \mathrm{~m}^{-2} \mathrm{yr}^{-1}\right)$. This reflects the model's inability to simulate the timing and magnitude of the observed dimming trend in SSR values between 1975 and 1989 (Fig. 13). Over this period the simulated and observed SSR values have a lower correlation $\left(r^{2}=0.80\right)$ and larger error $(\mathrm{RMSE}=8.43$ ) than the 1990-2009 period, indicating a slightly poorer representation by the model. The model without ARE also shows similar disagreements (Table 5), potentially indicating that errors in the simulation of aerosol are not causing simulated discrepancy in SSR during this period.

Over the period 1960-1974, simulated European annual mean SSR remained relatively constant (Fig. 13) and is of a similar magnitude (Table 5) to that observed. Over this period the observed SSR anomalies are positive (compared to a 1980-2000 mean), whilst the modelled SSR anomalies are negative. The small observed trend of $-0.01 \pm 0.15 \mathrm{~W} \mathrm{~m}^{-2} \mathrm{yr}^{-1}$ over the period 1960-1974 is overestimated by the model $\left(-0.09 \pm 0.11 \mathrm{~W} \mathrm{~m}^{-2} \mathrm{yr}^{-1}\right)$. The stronger simulated negative trend in SSR between 1960 and 1974 indicates that the dimming observed in the period 1974-1989 occurs too early in the model. The model without ARE does not show a dimming trend over this period (but does have a large uncertainty; Table 5), which implies that the 


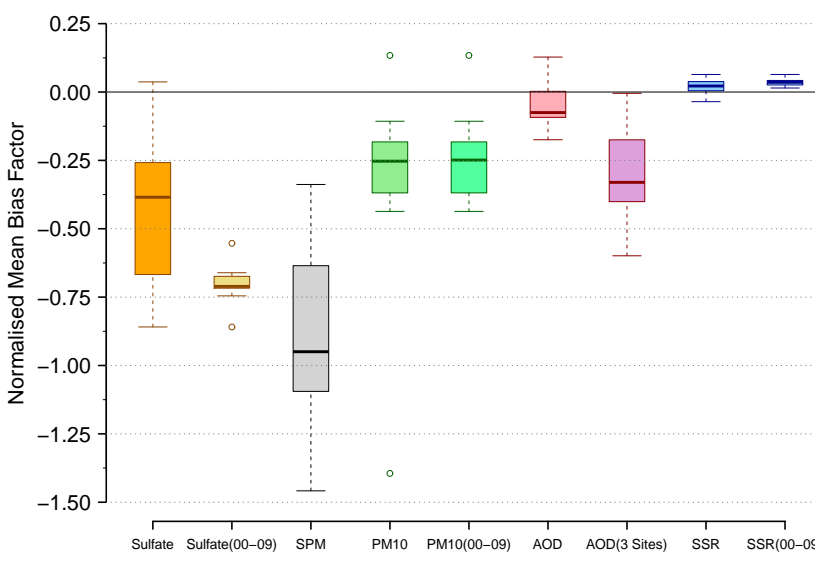

Figure 14. European normalised mean bias factors for sulfate aerosol mass, SPM mass, PM $_{10}$ mass, AOD and SSR across all the years where data were available (see Tables 2-5) and separately for the period 2000-2009. The solid line shows the median value, the boxes show the 25 th and 75 th percentile values with the error bars showing the maximum and minimum values and the circles representing outliers (values $>1.5 \times$ interquartile range).

discrepancy in the SSR trend could be due to uncertainties in simulated aerosols.

Understanding the discrepancy in simulated SSR prior to 1980 is difficult because aerosol observations are not available. Possible causes of model discrepancy include errors in simulated aerosol, problems with the observations, or the ECMWF reanalysis product. With regards to observational uncertainties, there were fewer observations of SSR before 1970 (Fig. 3) and there is also a larger correction factor associated with data from the available sites (Sanchez-Lorenzo et al., 2013). This suggests that observational error may be larger in the early period. Prior to 2000 , the model is forced by the ERA-40 reanalysis. ERA-40 was improved in the 1970s by the inclusion of additional measurements, most notably from satellites (Uppala et al., 2005). Larger errors in the reanalyses prior to 1980 (Uppala et al., 2005) could cause errors in the generation of clouds by the host GCM (global circulation model), which would affect simulated SSR.

\subsubsection{Evaluation summary}

Figure 14 summarises the comparison between simulated and observed sulfate, SPM, PM 10 , AOD and SSR across Europe separately for their entire operational period and also for the period 2000-2009 (when $\mathrm{PM}_{10}$ and AOD observations are available). The model underpredicts SPM, $\mathrm{PM}_{10}$ and sulfate aerosol mass over both periods. The largest underprediction occurs for SPM $(1978-1998, \mathrm{NMBF}=-0.88)$, with smaller underpredictions for sulfate (1978-2009, NMBF $=-0.38)$ and $\mathrm{PM}_{10}(1997-2009, \mathrm{NMBF}=-0.22)$. Simulated European annual mean SSR has a smaller model bias (1960-2009, NMBF =0.02). Over the period 2000-2009, the model has comparatively small biases in AOD (NMBF

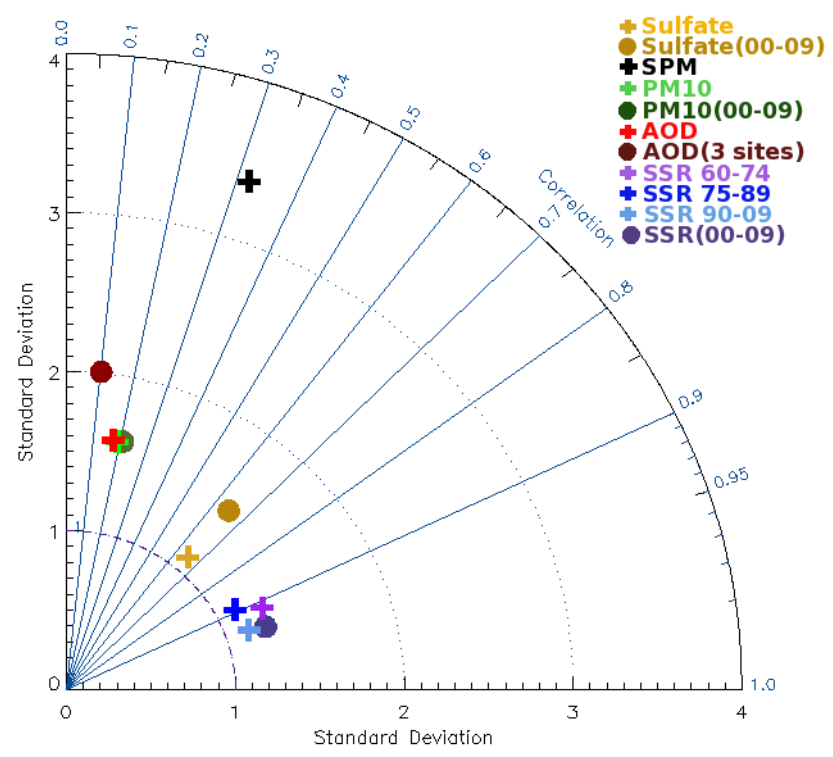

Figure 15. Taylor diagram comparing simulated and observed European sulfate mass concentrations, SPM, PM 10 , AOD and SSR. Comparisons are made across all the years where observations are available. We additionally show results for the period 2000-2009, where sulfate, $\mathrm{PM}_{10}$, AOD and SSR are consistently available. For AOD, we separately plot the three locations with the longest observational record. For SSR we also plot the three different time periods (1960-1974, 1975-1989, 1990-2009). Correlation coefficients are plotted against the observed standard deviations normalised relative to the simulated standard deviation.

$=-0.013)$ and SSR $(\mathrm{NMBF}=0.036)$ but larger biases for sulfate $(\mathrm{NMBF}=-0.71)$ and $\mathrm{PM}_{10}(\mathrm{NMBF}=-0.22)$. The model also underestimates aerosol number concentrations across the $\mathrm{N} 30(\mathrm{NMBF}=-0.85), \mathrm{N} 50(\mathrm{NMBF}=-0.65)$ and N100 (NMBF $=-0.96)$ size fractions in 2008-2009. Underestimation of annual and seasonal mean surface sulfate, $\mathrm{PM}_{10}$ and aerosol number concentration is therefore not manifested in the simulation of the annual and seasonal cycle of AOD or SSR. Calculation of AOD requires information on the aerosol vertical profile, aerosol optics, aerosol size distribution and atmospheric humidity. Simulation of SSR strongly depends on model representation of clouds. A direct comparison of model performance in simulating surface aerosol mass with AOD or SSR is therefore complicated. Figure 15 shows the spatial correlation and variability (represented by the standard deviation in observed values normalised to the modelled values, $\mathrm{SD}_{\mathrm{obs}} / \mathrm{SD}_{\bmod }$ ) in sulfate, SPM, $\mathrm{PM}_{10}$, AOD and SSR. In general, SSR and sulfate are better simulated in terms of spatial correlation and variability, with poorer model simulation of SPM, PM 10 and AOD.

The observed negative trends in sulfate, $\mathrm{PM}_{10}$ and $\mathrm{AOD}$ $\left(-0.05 \mu \mathrm{g} \mathrm{S} \mathrm{m}^{-3} \mathrm{yr}^{-1},-0.27 \mu \mathrm{g} \mathrm{m}^{-3} \mathrm{yr}^{-1}\right.$ and $\left.-0.007 \mathrm{yr}^{-1}\right)$ are all well reproduced by the model $\left(-0.04 \mu \mathrm{g} \mathrm{S} \mathrm{m}^{-3} \mathrm{yr}^{-1}\right.$, $-0.14 \mu \mathrm{g} \mathrm{m}^{-3} \mathrm{yr}^{-1}$ and $\left.-0.006 \mathrm{yr}^{-1}\right)$. Over the period 1990 2009 , observed trends in $\operatorname{SSR}\left(0.37 \mathrm{~W} \mathrm{~m}^{-2} \mathrm{yr}^{-1}\right)$ are also 
Table 6. Global and European shortwave top of atmosphere all-sky and clear-sky aerosol RF, relative to a 1980-2000 mean. Values for 1972 are included as this is when the simulated minimum aerosol RF occurs over Europe. For comparison we include global carbon dioxide RF (relative to 1750) from the IPCC fifth assessment report (Myhre et al., 2013).

\begin{tabular}{ccr|rr|c}
\hline Year & \multicolumn{2}{l|}{$\begin{array}{l}\text { All-sky aerosol } \\
\mathrm{RF}\left(\mathrm{W} \mathrm{m}^{-2}\right)\end{array}$} & \multicolumn{2}{|c|}{$\begin{array}{l}\text { Clear-sky aerosol } \\
\mathrm{RF}\left(\mathrm{W} \mathrm{m}^{-2}\right)\end{array}$} & $\begin{array}{c}\text { Estimates of } \mathrm{CO}_{2} \mathrm{RF} \\
(\text { Myhre et al., 2013) }\end{array}$ \\
\cline { 2 - 6 } & Global & Europe & Global & Europe & Global \\
\hline 1960 & +0.9 & +0.8 & +0.4 & +0.2 & +0.7 \\
1970 & -0.1 & -1.0 & +0.01 & -0.1 & +0.9 \\
1972 & -0.1 & -1.4 & +0.2 & -1.6 & $\mathrm{NA}$ \\
1980 & -0.4 & -0.6 & +0.01 & -0.5 & +1.1 \\
1990 & +0.01 & +0.1 & +0.04 & -0.1 & +1.3 \\
2000 & +0.4 & +1.7 & -0.1 & +1.1 & +1.5 \\
2009 & +0.3 & +2.1 & +0.1 & +1.9 & +1.8 \\
\hline
\end{tabular}

well simulated by the model when ARE are included $\left(0.32 \mathrm{~W} \mathrm{~m}^{-2} \mathrm{yr}^{-1}\right)$, but poorly simulated when ARE are excluded $\left(0.09 \mathrm{~W} \mathrm{~m}^{-2} \mathrm{yr}^{-1}\right)$. This confirms that being able to simulate the decline in aerosol concentrations over Europe is important for reproducing the observed brightening trend in SSR between 1990 and 2009. Prior to 1990, the model does not simulate trends in SSR as well but few aerosol observations are available to determine the reason for model failure, which could be caused by issues with simulated aerosol, clouds or with the observations.

\section{European aerosol radiative forcing trends}

Figure 16 shows the changes in simulated European mean top of atmosphere (TOA) outgoing radiation, relative to a 1980-2000 mean, under all-sky (Fig. 16a) and clear-sky conditions (Fig. 16b) with the numbers presented in Table 6 . Here we define this difference in TOA radiation as a radiative forcing (RF) between the current year and the long-term mean state. European mean all-sky RF (Fig. 16a) decreases by $>2.0 \mathrm{~W} \mathrm{~m}^{-2}$ (cooling trend) over the period 1960-1972, corresponding to the increase in simulated aerosol loading. From 1973 to 2009, European mean all-sky radiation increases by $>3.0 \mathrm{~W} \mathrm{~m}^{-2}$ (warming trend), corresponding to the simulated reduction of aerosols. All-sky RF showed the largest increase of $6.0 \mathrm{~W} \mathrm{~m}^{-2}$ over central Europe between 1973 and 2009, which is consistent with this region having experienced the largest change in anthropogenic emissions (Fig. 2) and aerosol concentrations (Fig. 8). Other regions of Europe have a similar temporal change but with a smaller magnitude.

The simulated clear-sky aerosol TOA RF (Fig. 16b) is similar to that simulated under all-sky conditions. European mean clear-sky RF decreased by $>1.5 \mathrm{~W} \mathrm{~m}^{-2}$ between 1960 and 1972 (cooling) and from 1973 to 2009 it increased by $>3.0 \mathrm{~W} \mathrm{~m}^{-2}$ (warming). Marmer et al. (2007) reported a similar change of $+2.0 \mathrm{~W} \mathrm{~m}^{-2}$ in the direct shortwave
RF from sulfate aerosols over Europe between 1980 and 2000. This indicates the strong influence directly exerted by aerosols on the European radiative balance in response to changes in anthropogenic emissions. An estimate of the cloud albedo effect is obtained as the difference between the all-sky and clear-sky RF. Over the period 1973-2009, the cloud albedo effect is estimated to have increased by $0.44 \mathrm{~W} \mathrm{~m}^{-2}$ (warming), indicating that it is a relatively small change when compared to that from the direct effect.

The changes in aerosol RF we simulate over Europe are slightly larger than those calculated for the USA by Leibensperger et al. (2012) of approximately $+1 \mathrm{~W} \mathrm{~m}^{-2}$ for the direct effect and $+1 \mathrm{~W} \mathrm{~m}^{-2}$ for the indirect (first and second) effects. The smaller changes in aerosol RF reported by Leibensperger et al. (2012) are possibly related to the smaller reductions in sulfate aerosol mass concentrations observed over the USA of $\sim 0.8 \mu \mathrm{g} \mathrm{S} \mathrm{m}{ }^{-3}(40 \%)$ when compared to those observed over Europe of $1.2 \mu \mathrm{g} \mathrm{S} \mathrm{m}^{-3}$ (70\%).

The calculated changes in all-sky TOA RF indicate the extent to which changes in anthropogenic emissions over the last 50 years have affected the European radiative balance. Reductions in anthropogenic aerosols have resulted in a positive response in the European radiative balance. We estimate that the magnitude of these emission reductions has caused European mean all-sky RF to increase by $>3.0 \mathrm{~W} \mathrm{~m}^{-2}$ between the mid-1970s and 2009, mainly due to the direct aerosol effect (as shown by similar changes in the clear-sky RF). Table 6 shows that the change in European mean aerosol $\mathrm{RF}$ is much larger than the change in global mean aerosol RF of $+0.4 \mathrm{~W} \mathrm{~m}^{-2}$. Shindell et al. (2013) reported a multimodel evaluation of aerosol RF over the period 1850-2100, with six of the nine models reporting a positive increase in global mean aerosol RF between 1980 and 2000, qualitatively similar to the results presented here. At the global scale, our simulated change in all-sky aerosol RF between 1970 and 2009 is $\sim 40 \%$ of the magnitude of change in global $\mathrm{CO}_{2}$ radiative forcing over the same period. At the European scale, the simulated change in all-sky aerosol RF is more than 3 times the change in global mean $\mathrm{CO}_{2} \mathrm{RF}$. This indicates the large regional impact that decreasing aerosol concentrations have had on the radiative balance and climate over Europe compared to other forcing agents.

The agreement between the model and observations in the changes in aerosols and in the brightening period of the surface radiation balance between the 1990 and 2009 improve our confidence in the magnitude and temporal change of the simulated TOA RF over this period when most of the change occurs $\left(2.0 \mathrm{~W} \mathrm{~m}^{-2}\right)$. Future work needs to explore the potential climate implications from these changes to the radiative balance. It will be important to understand the role of European air quality legislation in observed emission reductions as this may have important implications when considering the impact of future air quality mitigation measures on climate. 


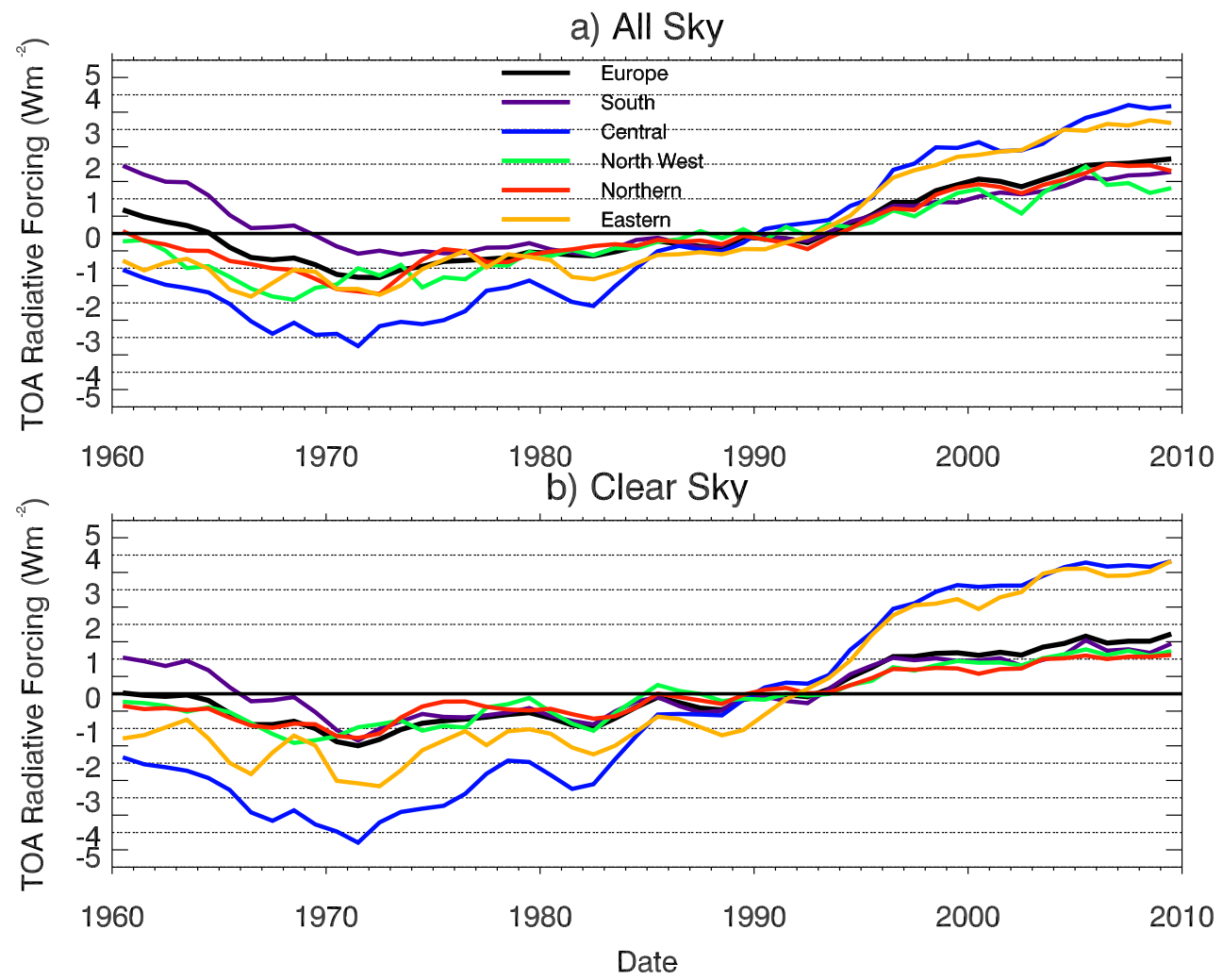

Figure 16. European and sub-regional top of atmosphere aerosol radiative forcing $\left(\mathrm{Wm}^{-2}\right.$ ), relative to a 1980-2000 average, under (a) all-sky and (b) clear-sky conditions. European regions are as defined in Fig. 1

\section{Conclusions}

We used the HadGEM3-UKCA coupled chemistry-climate model to simulate changes in aerosols between 1960 and 2009, a period over which anthropogenic sources of aerosol changed substantially. We evaluated the model against European observations of sulfate aerosol mass, total SPM, $\mathrm{PM}_{10}$ mass concentrations, aerosol number concentrations, AOD and surface SSR. We also calculated the impact of changes in atmospheric aerosols on European aerosol radiative forcing.

The model underpredicts sulfate aerosol mass concentrations $(\mathrm{NMBF}=-0.4)$, SPM $(1978-1998, \mathrm{NMBF}=-0.9)$ and $\mathrm{PM}_{10}(1997-2009, \mathrm{NMBF}=-0.2)$. In addition, the model underpredicts present-day aerosol number concentrations over the size fractions of $\mathrm{N} 30(\mathrm{NMBF}=-0.85)$, $\mathrm{N} 50(\mathrm{NMBF}=-0.65)$ and $\mathrm{N} 100(\mathrm{NMBF}=-0.96)$. Underestimation of aerosol number and mass could be due to uncertainties in the observations (Tørseth et al., 2012), an overestimation of deposition processes or underestimated sources of PM including nitrate, anthropogenic SOA, domestic biomass combustion, dust and primary biological aerosol particles. The larger underestimation of particles with diameters $>10 \mu \mathrm{m}$ suggests that the sources of such particles may be more uncertain and are not well treated by the model. The model particularly underestimates sulfate in winter and over northern Europe potentially due to an under-representation of the in-cloud oxidation of sulfur species to sulfate via reaction with ozone or an enhanced wet deposition rate, caused by artificial high drizzle precipitation. Biases in simulated AOD (2000-2009, $\mathrm{NMBF}=-0.01)$ are smaller than for surface aerosol concentrations. Calculation of AOD requires information on the aerosol vertical profile, aerosol optics, aerosol size distribution and atmospheric humidity and complicates any direct comparison between surface aerosol mass and AOD.

Observed trends in surface aerosol mass and AOD were generally well represented by the model. Sulfate aerosol mass declines by $68 \%$ in the observations and by $78 \%$ in the model between 1978 and 2009, consistent with the decrease in $\mathrm{SO}_{2}$ emissions over Europe. The observed European annual mean SPM decreased by $42 \%$ between 1978 and 1998, compared to a simulated decrease of $20 \%$. Between 1997 and $2009 \mathrm{PM}_{10}$ mass concentrations decreased by $9 \%$ in the observations and by $8 \%$ in the model. Between 2000 and 2009 AOD decreased by $11 \%$ in the observations and by $14 \%$ in the model at observation sites with more than 9 years of data.

The all-sky European SSR was shown to increase between 1990 and 2009 in both the model $\left(4.0 \mathrm{~W} \mathrm{~m}^{-2}\right)$ and 
observations $\left(5.8 \mathrm{~W} \mathrm{~m}^{-2}\right)$ (brightening). In the model simulation where aerosol radiative effects were excluded, European all-sky SSR increased by only $0.3 \mathrm{~W} \mathrm{~m}^{-2}$. This comparison suggests that observed brightening post-1990 is driven by changes in aerosol that are well captured by the model. Accounting for changes to aerosols is therefore important to reproduce the European brightening trend from 1990 to 2009.

Prior to 1990, there are discrepancies between observed and simulated all-sky SSR anomalies. Specifically, the model is unable to reproduce the magnitude and timing of the observed reduction in SSR values (dimming). These errors in SSR coincide with the largest model bias in observed SPM concentrations between 1978 and 1980 (Fig. 8c), but the lack of extensive aerosol observations prior to 1980 prevents isolation of the cause of this model observational discrepancy in SSR. Possible reasons include errors in simulated aerosols, errors associated with the meteorological reanalysis fields, and issues with the measurement data (less SSR observations were available before 1970).

From the peak in aerosol loading in the early 1970s, European all-sky aerosol TOA radiative forcing has increased by $>3.0 \mathrm{~W} \mathrm{~m}^{-2}$, due to a reduction in the aerosol cooling effect. Changes in European mean RF are mainly due to changes in the direct aerosol effect, as shown by the similarity between clear-sky and all-sky RF. The largest RF is over central Europe $\left(+6.0 \mathrm{~W} \mathrm{~m}^{-2}\right)$, which has seen the largest change in anthropogenic emissions and aerosol concentrations. The change in European mean aerosol RF is much larger than that globally and also 3 times as large as the change in global mean $\mathrm{CO}_{2}$ RF over the period 1970-2009. Our evaluation showed that the model is able to reproduce the observed changes in SSR over the period 1990-2009, during which two-thirds of the simulated change in RF occurred $\left(2.0 \mathrm{~W} \mathrm{~m}^{-2}\right)$. Our evaluation therefore provides confidence in the simulated changes of TOA RF. The reductions in anthropogenic aerosol emissions over this period have resulted in a positive response in the radiative balance over Europe, which may have contributed to increasing temperatures across Europe (Philipona et al., 2009). The RFs simulated in this work are similar in magnitude to those reported by Marmer et al. (2007) over Europe and by Leibensperger et al. (2012) over the USA. The change in anthropogenic aerosol emissions over the period 1970-2009, in part due to measures to improve air quality, has led to a considerable reduction in the concentrations of aerosols over Europe. This decrease in aerosols has reduced the aerosol radiative cooling effect over Europe. Attempts to improve European air quality over the last 30-40 years have potentially had nonnegligible impacts on European climate (Arneth et al., 2009; Philipona et al., 2009; Ramanathan and Feng, 2009; Fiore et al., 2012) and should be the subject of future study. These air quality-climate interactions should be considered when designing any future measures to improve air quality and mitigate climate change.
Acknowledgements. Steven Turnock would like to acknowledge the funding for his PhD studentship from the Natural Environment Research Council (NERC) and Met Office. For making their data available to be used in this study we would like to acknowledge the EMEP, GEBA and AERONET measurement networks along with any data managers involved in data collection. We would also like to acknowledge Ari Asmi for providing the aerosol size distribution data from the EUSAAR and GUAN networks and Carly Reddington for pre-processing this data set for use in the model evaluation. Anthropogenic and biomass-burning emissions from the MACCity data set were retrieved from the ECCAD emissions server. This work was also made possible by participation in the EU Framework 7 PEGASOS project (no. 265148). We acknowledge use of the MONSooN system, a collaborative facility supplied under the Joint Weather and Climate Research Programme, a strategic partnership between the Met Office and the Natural Environment Research Council. Matthew Woodhouse would like to thank the Royal Society for support via the International Exchange Scheme. Arturo Sanchez-Lorenzo was supported by a postdoctoral fellowship JCI-2012-12508 and projects CGL2014-55976-R, CGL2014-52135-C3-1-R financed by the Spanish Ministry of Economy and Competitiveness.

Edited by: A. Hofzumahaus

\section{References}

Allen, R. J., Norris, J. R., and Wild, M.: Evaluation of multidecadal variability in CMIP5 surface solar radiation and inferred underestimation of aerosol direct effects over Europe, China, Japan, and India, J. Geophys. Res.-Atmos., 118, 6311-6336, doi:10.1002/jgrd.50426, 2013.

Arneth, A., Unger, N., Kulmala, M., and Andreae, M. O.: Clean the Air, Heat the Planet?, Science, 326, 672-673, doi:10.1126/science.1181568, 2009.

Asmi, A., Wiedensohler, A., Laj, P., Fjaeraa, A.-M., Sellegri, K., Birmili, W., Weingartner, E., Baltensperger, U., Zdimal, V., Zikova, N., Putaud, J.-P., Marinoni, A., Tunved, P., Hansson, H.C., Fiebig, M., Kivekäs, N., Lihavainen, H., Asmi, E., Ulevicius, V., Aalto, P. P., Swietlicki, E., Kristensson, A., Mihalopoulos, N., Kalivitis, N., Kalapov, I., Kiss, G., de Leeuw, G., Henzing, B., Harrison, R. M., Beddows, D., O'Dowd, C., Jennings, S. G., Flentje, H., Weinhold, K., Meinhardt, F., Ries, L., and Kulmala, M.: Number size distributions and seasonality of submicron particles in Europe 2008-2009, Atmos. Chem. Phys., 11, 5505-5538, doi:10.5194/acp-11-5505-2011, 2011.

Asmi, A., Collaud Coen, M., Ogren, J. A., Andrews, E., Sheridan, P., Jefferson, A., Weingartner, E., Baltensperger, U., Bukowiecki, N., Lihavainen, H., Kivekäs, N., Asmi, E., Aalto, P. P., Kulmala, M., Wiedensohler, A., Birmili, W., Hamed, A., O’Dowd, C., G Jennings, S., Weller, R., Flentje, H., Fjaeraa, A. M., Fiebig, M., Myhre, C. L., Hallar, A. G., Swietlicki, E., Kristensson, A., and Laj, P.: Aerosol decadal trends - Part 2: In-situ aerosol particle number concentrations at GAW and ACTRIS stations, Atmos. Chem. Phys., 13, 895-916, doi:10.5194/acp-13-895-2013, 2013. Barmpadimos, I., Keller, J., Oderbolz, D., Hueglin, C., and Prévôt, A. S. H.: One decade of parallel fine $\left(\mathrm{PM}_{2.5}\right)$ and coarse $\left(\mathrm{PM}_{10}-\mathrm{PM}_{2.5}\right)$ particulate matter measurements in Europe: 
trends and variability, Atmos. Chem. Phys., 12, 3189-3203, doi:10.5194/acp-12-3189-2012, 2012.

Bellouin, N., Rae, J., Jones, A., Johnson, C., Haywood, J., and Boucher, O.: Aerosol forcing in the Climate Model Intercomparison Project (CMIP5) simulations by HadGEM2-ES and the role of ammonium nitrate, J. Geophys. Res., 116, D20206, doi:10.1029/2011JD016074, 2011.

Bellouin, N., Mann, G. W., Woodhouse, M. T., Johnson, C., Carslaw, K. S., and Dalvi, M.: Impact of the modal aerosol scheme GLOMAP-mode on aerosol forcing in the Hadley Centre Global Environmental Model, Atmos. Chem. Phys., 13, 30273044, doi:10.5194/acp-13-3027-2013, 2013.

Berglen, T. F., Myhre, G., Isaksen, I. S., Vestreng, V., and Smith, S. J.: Sulphate trends in Europe: are we able to model the recent observed decrease?, Tellus B, 59, 773-786, doi:10.3402/tellusb.v59i4.17056, 2007.

Boucher, O., Randall, P., Artaxo, P., Bretherton, C., Feingold, G., Forster, P., Kerminen, V.-M., Kondo, Y., Liao, H., Lohmann, U., Rasch, P., Satheesh, S. K., Sherwood, S., Stevens, B., and Zhang, X. Y.: Clouds and Aerosols, in: Climate Change 2013: The Physical Science Basis. Contribution of Working Group I to the Fifth Assessment Report of the Intergovernmental Panel on Climate Change, Cambridge University Press, Cambridge, 2013.

Chalmers, N., Highwood, E. J., Hawkins, E., Sutton, R., and Wilcox, L. J.: Aerosol contribution to the rapid warming of near-term climate under RCP 2.6, Geophys. Res. Lett., 39, 2-7, doi:10.1029/2012GL052848, 2012.

Chiacchio, M., Solmon, F., Giorgi, F., Stackhouse, P., and Wild, M.: Evaluation of the radiation budget with a regional climate model over Europe and inspection of dimming and brightening, J. Geophys. Res.-Atmos., 120, 1951-1971, doi:10.1002/2014JD022497, 2015.

Chin, M., Diehl, T., Tan, Q., Prospero, J. M., Kahn, R. A., Remer, L. A., Yu, H., Sayer, A. M., Bian, H., Geogdzhayev, I. V., Holben, B. N., Howell, S. G., Huebert, B. J., Hsu, N. C., Kim, D., Kucsera, T. L., Levy, R. C., Mishchenko, M. I., Pan, X., Quinn, P. K., Schuster, G. L., Streets, D. G., Strode, S. A., Torres, O., and Zhao, X.-P.: Multi-decadal aerosol variations from 1980 to 2009: a perspective from observations and a global model, Atmos. Chem. Phys., 14, 3657-3690, doi:10.5194/acp-14-3657-2014, 2014.

Colette, A., Granier, C., Hodnebrog, Ø., Jakobs, H., Maurizi, A., Nyiri, A., Bessagnet, B., D’Angiola, A., D’Isidoro, M., Gauss, M., Meleux, F., Memmesheimer, M., Mieville, A., Rouïl, L., Russo, F., Solberg, S., Stordal, F., and Tampieri, F.: Air quality trends in Europe over the past decade: a first multi-model assessment, Atmos. Chem. Phys., 11, 11657-11678, doi:10.5194/acp11-11657-2011, 2011.

Collaud Coen, M., Andrews, E., Asmi, A., Baltensperger, U., Bukowiecki, N., Day, D., Fiebig, M., Fjaeraa, A. M., Flentje, H., Hyvärinen, A., Jefferson, A., Jennings, S. G., Kouvarakis, G., Lihavainen, H., Lund Myhre, C., Malm, W. C., Mihapopoulos, N., Molenar, J. V., O'Dowd, C., Ogren, J. A., Schichtel, B. A., Sheridan, P., Virkkula, A., Weingartner, E., Weller, R., and Laj, P.: Aerosol decadal trends - Part 1: In-situ optical measurements at GAW and IMPROVE stations, Atmos. Chem. Phys., 13, 869894, doi:10.5194/acp-13-869-2013, 2013.

COMEAP: The Mortality Effects of Long-term Exposure to Particulate Air Pollution in the United Kingdom, Tech. rep., Health
Protection Agency for the Committee on the Medical Effects of Air Pollutants, 2010.

Davies, T., Cullen, M. J. P., Malcolm, A. J., Mawson, M. H., Staniforth, A., White, A. A., and Wood, N.: A new dynamical core for the Met Office's global and regional modelling of the atmosphere, Q. J. Roy. Meteor. Soc., 131, 1759-1782, doi:10.1256/qj.04.101, 2005.

de Meij, A., Krol, M., Dentener, F., Vignati, E., Cuvelier, C., and Thunis, P.: The sensitivity of aerosol in Europe to two different emission inventories and temporal distribution of emissions, Atmos. Chem. Phys., 6, 4287-4309, doi:10.5194/acp-6-4287-2006, 2006.

Dee, D. P., Uppala, S. M., Simmons, A. J., Berrisford, P., Poli, P., Kobayashi, S., Andrae, U., Balmaseda, M. A., Balsamo, G., Bauer, P., Bechtold, P., Beljaars, A. C. M., van de Berg, L., Bidlot, J., Bormann, N., Delsol, C., Dragani, R., Fuentes, M., Geer, A. J., Haimberger, L., Healy, S. B., Hersbach, H., Hólm, E. V., Isaksen, L., Kå llberg, P., Köhler, M., Matricardi, M., McNally, A. P., Monge-Sanz, B. M., Morcrette, J.-J., Park, B.-K., Peubey, C., de Rosnay, P., Tavolato, C., Thépaut, J.-N., and Vitart, F.: The ERA-Interim reanalysis: configuration and performance of the data assimilation system, Q. J. Roy. Meteor. Soc., 137, 553-597, doi:10.1002/qj.828, 2011.

Edwards, J. M. and Slingo, A.: Studies with a flexible new radiation code. I: Choosing a configuration for a largescale model, Q. J. Roy. Meteorol. Soc., 122, 689-719, doi:10.1002/qj.49712253107, 1996.

Essery, R. L. H., Best, M. J., Betts, R., and Cox, P. M.: Explicit Representation of Subgrid Heterogeneity in a GCM Land Surface Scheme, J. Hydrometeor., 4, 530-543, 2002.

Fagerli, H. and Aas, W.: Trends of nitrogen in air and precipitation: Model results and observations at EMEP sites in Europe, 19802003, Environ. Pollut., 154, 448-461, 2008.

Farina, S. C., Adams, P. J., and Pandis, S. N.: Modeling global secondary organic aerosol formation and processing with the volatility basis set: Implications for anthropogenic secondary organic aerosol, J. Geophys. Res., 115, D09202, doi:10.1029/2009JD013046, 2010.

Fiore, A. M., Naik, V., Spracklen, D. V., Steiner, A., Unger, N., Prather, M., Bergmann, D., Cameron-Smith, P. J., Cionni, I., Collins, W. J., Dals $\emptyset$ ren, S., Eyring, V., Folberth, G. a., Ginoux, P., Horowitz, L. W., Josse, B., Lamarque, J.-F., MacKenzie, I. a., Nagashima, T., O’Connor, F. M., Righi, M., Rumbold, S. T., Shindell, D. T., Skeie, R. B., Sudo, K., Szopa, S., Takemura, T., and Zeng, G.: Global air quality and climate., Chem. Soc. Rev., 41, 6663-83, doi:10.1039/c2cs35095e, 2012.

Folini, D. and Wild, M.: Aerosol emissions and dimming/brightening in Europe: Sensitivity studies with ECHAM5-HAM, J. Geophys. Res., 116, D21104, doi:10.1029/2011JD016227, 2011.

Gong, S. L.: A parameterization of sea-salt aerosol source function for sub- and super-micron particles, Global Biogeochem. Cy., 17, 1097, doi:10.1029/2003GB002079, 2003.

Granier, C., Bessagnet, B., Bond, T. C., D’Angiola, A., Denier van der Gon, H., Frost, G. J., Heil, A., Kaiser, J. W., Kinne, S., Klimont, Z., Kloster, S., Lamarque, J.-F., Liousse, C., Masui, T., Meleux, F., Mieville, A., Ohara, T., Raut, J.-C., Riahi, K., Schultz, M. G., Smith, S. J., Thompson, A., Aardenne, J., Werf, G. R., and Vuuren, D. P.: Evolution of anthropogenic and 
biomass burning emissions of air pollutants at global and regional scales during the 1980-2010 period, Clim. Change, 109, 163-190, doi:10.1007/s10584-011-0154-1, 2011.

Guenther, A., Hewitt, C. N., Erickson, D., Fall, R., Geron, C., Graedel, T., Harley, P., Klinger, L., Lerdau, M., Mckay, W. A., Pierce, T., Scholes, B., Steinbrecher, R., Tallamraju, R., Taylor, J., and Zimmerman, P.: A global model of natural volatile organic compound emissions, J. Geophys. Res., 100, 8873, doi:10.1029/94JD02950, 1995.

Hand, J. L., Schichtel, B. A., Malm, W. C., and Pitchford, M. L.: Particulate sulfate ion concentration and $\mathrm{SO}_{2}$ emission trends in the United States from the early 1990s through 2010, Atmos. Chem. Phys., 12, 10353-10365, doi:10.5194/acp-1210353-2012, 2012.

Harrison, R. M., Stedman, J., and Derwent, D.: New Directions: Why are PM10 concentrations in Europe not falling?, Atmos. Environ., 42, 603-606, doi:10.1016/j.atmosenv.2007.11.023, 2008.

Heald, C. L. and Spracklen, D. V.: Atmospheric budget of primary biological aerosol particles from fungal spores, Geophys. Res. Lett., 36, 1-5, doi:10.1029/2009GL037493, 2009.

Hewitt, H. T., Copsey, D., Culverwell, I. D., Harris, C. M., Hill, R. S. R., Keen, A. B., McLaren, A. J., and Hunke, E. C.: Design and implementation of the infrastructure of HadGEM3: the nextgeneration Met Office climate modelling system, Geosci. Model Dev., 4, 223-253, doi:10.5194/gmd-4-223-2011, 2011.

Hodzic, A., Madronich, S., Bohn, B., Massie, S., Menut, L., and Wiedinmyer, C.: Wildfire particulate matter in Europe during summer 2003: meso-scale modeling of smoke emissions, transport and radiative effects, Atmos. Chem. Phys., 7, 4043-4064, doi:10.5194/acp-7-4043-2007, 2007.

Holben, B., Eck, T., Slutsker, I., Tanré, D., Buis, J., Setzer, A., Vermote, E., Reagan, J., Kaufman, Y., Nakajima, T., Lavenu, F., Jankowiak, I., and Smirnov, A.: AERONET-A Federated Instrument Network and Data Archive for Aerosol Characterization, Remote Sens. Environ., 66, 1-16, doi:10.1016/S00344257(98)00031-5, 1998.

Hurrell, J. W., Hack, J. J., Shea, D., Caron, J. M., and Rosinski, J.: A New Sea Surface Temperature and Sea Ice Boundary Dataset for the Community Atmosphere Model, J. Climate, 21, 5145-5153, doi:10.1175/2008JCLI2292.1, 2008.

Jones, A., Roberts, D. L., Woodage, M. J., and Johnson, C. E.: Indirect sulphate aerosol forcing in a climate model with an interactive sulphur cycle, J. Geophys. Res., 106, 20293, doi:10.1029/2000JD000089, 2001.

Kettle, A. J. and Andreae, M. O.: Flux of dimethylsulfide from the oceans: A comparison of updated data sets and flux models, J. Geophys. Res., 105, 26793, doi:10.1029/2000JD900252, 2000.

Koch, D., Bauer, S. E., Del Genio, A., Faluvegi, G., McConnell, J. R., Menon, S., Miller, R. L., Rind, D., Ruedy, R., Schmidt, G. a., and Shindell, D. T.: Coupled Aerosol-Chemistry-Climate Twentieth-Century Transient Model Investigation: Trends in Short-Lived Species and Climate Responses, J. Climate, 24, 2693-2714, doi:10.1175/2011JCLI3582.1, 2011.

Kreidenweis, S. M.: Modification of aerosol mass and size distribution due to aqueous-phase $\mathrm{SO}_{2}$ oxidation in clouds: Comparisons of several models, J. Geophys. Res., 108, 4213, doi:10.1029/2002JD002697, 2003.

Lamarque, J.-F., Bond, T. C., Eyring, V., Granier, C., Heil, A., Klimont, Z., Lee, D., Liousse, C., Mieville, A., Owen, B.,
Schultz, M. G., Shindell, D., Smith, S. J., Stehfest, E., Van Aardenne, J., Cooper, O. R., Kainuma, M., Mahowald, N., McConnell, J. R., Naik, V., Riahi, K., and van Vuuren, D. P.: Historical (1850-2000) gridded anthropogenic and biomass burning emissions of reactive gases and aerosols: methodology and application, Atmos. Chem. Phys., 10, 7017-7039, doi:10.5194/acp10-7017-2010, 2010.

Langmann, B., Varghese, S., Marmer, E., Vignati, E., Wilson, J., Stier, P., and O'Dowd, C.: Aerosol distribution over Europe: a model evaluation study with detailed aerosol microphysics, Atmos. Chem. Phys., 8, 1591-1607, doi:10.5194/acp-8-1591-2008, 2008.

Leibensperger, E. M., Mickley, L. J., Jacob, D. J., Chen, W.-T., Seinfeld, J. H., Nenes, A., Adams, P. J., Streets, D. G., Kumar, N., and Rind, D.: Climatic effects of 1950-2050 changes in US anthropogenic aerosols - Part 1: Aerosol trends and radiative forcing, Atmos. Chem. Phys., 12, 3333-3348, doi:10.5194/acp-12-33332012, 2012.

Liss, P. and Merlivat, L.: Air-Sea Gas Exchange Rates: Introduction and Synthesis, in: The Role of Air-Sea Exchange in Geochemical Cycling, 113-127, D. Reidel, 1986.

Manders, A. M. M., van Meijgaard, E., Mues, A. C., Kranenburg, R., van Ulft, L. H., and Schaap, M.: The impact of differences in large-scale circulation output from climate models on the regional modeling of ozone and PM, Atmos. Chem. Phys., 12 9441-9458, doi:10.5194/acp-12-9441-2012, 2012.

Manktelow, P. T., Mann, G. W., Carslaw, K. S., Spracklen, D. V., and Chipperfield, M. P.: Regional and global trends in sulfate aerosol since the 1980s, Geophys. Res. Lett., 34, L14803, doi:10.1029/2006GL028668, 2007.

Mann, G. W., Carslaw, K. S., Spracklen, D. V., Ridley, D. A., Manktelow, P. T., Chipperfield, M. P., Pickering, S. J., and Johnson, C. E.: Description and evaluation of GLOMAP-mode: a modal global aerosol microphysics model for the UKCA composition-climate model, Geosci. Model Dev., 3, 519-551, doi:10.5194/gmd-3-519-2010, 2010.

Mann, G. W., Carslaw, K. S., Ridley, D. A., Spracklen, D. V., Pringle, K. J., Merikanto, J., Korhonen, H., Schwarz, J. P., Lee, L. A., Manktelow, P. T., Woodhouse, M. T., Schmidt, A., Breider, T. J., Emmerson, K. M., Reddington, C. L., Chipperfield, M. P., and Pickering, S. J.: Intercomparison of modal and sectional aerosol microphysics representations within the same 3-D global chemical transport model, Atmos. Chem. Phys., 12, 4449-4476, doi:10.5194/acp-12-4449-2012, 2012.

Mann, G. W., Carslaw, K. S., Reddington, C. L., Pringle, K. J., Schulz, M., Asmi, A., Spracklen, D. V., Ridley, D. A., Woodhouse, M. T., Lee, L. A., Zhang, K., Ghan, S. J., Easter, R. C., Liu, X., Stier, P., Lee, Y. H., Adams, P. J., Tost, H., Lelieveld, J., Bauer, S. E., Tsigaridis, K., van Noije, T. P. C., Strunk, A., Vignati, E., Bellouin, N., Dalvi, M., Johnson, C. E., Bergman, T., Kokkola, H., von Salzen, K., Yu, F., Luo, G., Petzold, A., Heintzenberg, J., Clarke, A., Ogren, J. A., Gras, J., Baltensperger, U., Kaminski, U., Jennings, S. G., O’Dowd, C. D., Harrison, R. M., Beddows, D. C. S., Kulmala, M., Viisanen, Y., Ulevicius, V., Mihalopoulos, N., Zdimal, V., Fiebig, M., Hansson, H.-C., Swietlicki, E., and Henzing, J. S.: Intercomparison and evaluation of global aerosol microphysical properties among AeroCom models of a range of complexity, Atmos. Chem. Phys., 14, 4679-4713, doi:10.5194/acp-14-4679-2014, 2014. 
Marmer, E., Langmann, B., Fagerli, H., and Vestreng, V.: Direct shortwave radiative forcing of sulfate aerosol over Europe from 1900 to 2000, J. Geophys. Res., 112, D23S17, doi:10.1029/2006JD008037, 2007.

Morgenstern, O., Braesicke, P., O’Connor, F. M., Bushell, A. C., Johnson, C. E., Osprey, S. M., and Pyle, J. A.: Evaluation of the new UKCA climate-composition model - Part 1: The stratosphere, Geosci. Model Dev., 2, 43-57, doi:10.5194/gmd-2-432009, 2009.

Myhre, G., Shindell, D., Breon, F.-M., Collins, W., Fuglestvedt, J., Huang, J., Koch, D., Lamarque, J.-F., Lee, D., Mendoza, B., Nakajima, T., Robock, A., Stephens, G., Takemura, T., and Zhang, H.: Anthropogenic and Natural Radiative Forcing, in: Climate Change 2013: The Physical Science Basis. Contribution of Working Group I to the Fifth Assessment Report of the Intergovernemental Panel on Cliamte Change, Cambridge University Press, Cambridge, United Kingdom and New York, NY, USA, 2013.

O'Connor, F. M., Johnson, C. E., Morgenstern, O., Abraham, N. L., Braesicke, P., Dalvi, M., Folberth, G. A., Sanderson, M. G., Telford, P. J., Voulgarakis, A., Young, P. J., Zeng, G., Collins, W. J., and Pyle, J. A.: Evaluation of the new UKCA climatecomposition model - Part 2: The Troposphere, Geosci. Model Dev., 7, 41-91, doi:10.5194/gmd-7-41-2014, 2014.

Penner, J. E., Prather, M. J., Isaksen, I. S. a., Fuglestvedt, J. S., Klimont, Z., and Stevenson, D. S.: Short-lived uncertainty?, Nat. Geosci., 3, 587-588, doi:10.1038/ngeo932, 2010.

Philipona, R., Behrens, K., and Ruckstuhl, C.: How declining aerosols and rising greenhouse gases forced rapid warming in Europe since the 1980s, Geophys. Res. Lett., 36, L02806, doi:10.1029/2008GL036350,, 2009.

Pozzer, A., de Meij, A., Pringle, K. J., Tost, H., Doering, U. M., van Aardenne, J., and Lelieveld, J.: Distributions and regional budgets of aerosols and their precursors simulated with the EMAC chemistry-climate model, Atmos. Chem. Phys., 12, 961-987, doi:10.5194/acp-12-961-2012, 2012.

Ramanathan, V. and Feng, Y.: Air pollution, greenhouse gases and climate change: Global and regional perspectives, Atmos. Environ., 43, 37-50, doi:10.1016/j.atmosenv.2008.09.063, 2009.

Sanchez-Lorenzo, A., Wild, M., and Trentmann, J.: Validation and stability assessment of the monthly mean CM SAF surface solar radiation dataset over Europe against a homogenized surface dataset (1983-2005), Remote Sens. Environ., 134, 355-366, doi:10.1016/j.rse.2013.03.012, 2013.

Schultz, M. G., Heil, A., Hoelzemann, J. J., Spessa, A., Thonicke, K., Goldammer, J. G., Held, A. C., Pereira, J. M. C., and van het Bolscher, M.: Global wildland fire emissions from 1960 to 2000, Global Biogeochem. Cy., 22, GB2002, doi:10.1029/2007GB003031, 2008.

Scott, C. E., Rap, A., Spracklen, D. V., Forster, P. M., Carslaw, K. S., Mann, G. W., Pringle, K. J., Kivekäs, N., Kulmala, M., Lihavainen, H., and Tunved, P.: The direct and indirect radiative effects of biogenic secondary organic aerosol, Atmos. Chem. Phys., 14, 447-470, doi:10.5194/acp-14-447-2014, 2014.

Shindell, D. T., Lamarque, J.-F., Schulz, M., Flanner, M., Jiao, C., Chin, M., Young, P. J., Lee, Y. H., Rotstayn, L., Mahowald, N., Milly, G., Faluvegi, G., Balkanski, Y., Collins, W. J., Conley, A. J., Dalsoren, S., Easter, R., Ghan, S., Horowitz, L., Liu, X., Myhre, G., Nagashima, T., Naik, V., Rumbold, S. T., Skeie, R.,
Sudo, K., Szopa, S., Takemura, T., Voulgarakis, A., Yoon, J.-H., and Lo, F.: Radiative forcing in the ACCMIP historical and future climate simulations, Atmos. Chem. Phys., 13, 2939-2974, doi:10.5194/acp-13-2939-2013, 2013.

Skeie, R. B., Berntsen, T. K., Myhre, G., Tanaka, K., Kvalevåg, M. M., and Hoyle, C. R.: Anthropogenic radiative forcing time series from pre-industrial times until 2010, Atmos. Chem. Phys., 11, 11827-11857, doi:10.5194/acp-11-11827-2011, 2011.

Smith, S. J., van Aardenne, J., Klimont, Z., Andres, R. J., Volke, A., and Delgado Arias, S.: Anthropogenic sulfur dioxide emissions: 1850-2005, Atmos. Chem. Phys., 11, 1101-1116, doi:10.5194/acp-11-1101-2011, 2011.

Spracklen, D. V., Carslaw, K. S., Kulmala, M., Kerminen, V.-M., Mann, G. W., and Sihto, S.-L.: The contribution of boundary layer nucleation events to total particle concentrations on regional and global scales, Atmos. Chem. Phys., 6, 5631-5648, doi:10.5194/acp-6-5631-2006, 2006.

Spracklen, D. V., Jimenez, J. L., Carslaw, K. S., Worsnop, D. R., Evans, M. J., Mann, G. W., Zhang, Q., Canagaratna, M. R., Allan, J., Coe, H., McFiggans, G., Rap, A., and Forster, P.: Aerosol mass spectrometer constraint on the global secondary organic aerosol budget, Atmos. Chem. Phys., 11, 12109-12136, doi:10.5194/acp-11-12109-2011, 2011.

Tørseth, K., Aas, W., Breivik, K., Fjæraa, A. M., Fiebig, M., Hjellbrekke, A. G., Lund Myhre, C., Solberg, S., and Yttri, K. E.: Introduction to the European Monitoring and Evaluation Programme (EMEP) and observed atmospheric composition change during 1972-2009, Atmos. Chem. Phys., 12, 5447-5481, doi:10.5194/acp-12-5447-2012, 2012.

Tsigaridis, K., Daskalakis, N., Kanakidou, M., Adams, P. J., Artaxo, P., Bahadur, R., Balkanski, Y., Bauer, S. E., Bellouin, N., Benedetti, A., Bergman, T., Berntsen, T. K., Beukes, J. P., Bian, H., Carslaw, K. S., Chin, M., Curci, G., Diehl, T., Easter, R. C., Ghan, S. J., Gong, S. L., Hodzic, A., Hoyle, C. R., Iversen, T., Jathar, S., Jimenez, J. L., Kaiser, J. W., Kirkevåg, A., Koch, D., Kokkola, H., Lee, Y. H, Lin, G., Liu, X., Luo, G., Ma, X., Mann, G. W., Mihalopoulos, N., Morcrette, J.-J., Müller, J.-F., Myhre, G., Myriokefalitakis, S., Ng, N. L., O’Donnell, D., Penner, J. E., Pozzoli, L., Pringle, K. J., Russell, L. M., Schulz, M., Sciare, J., Seland, Ø., Shindell, D. T., Sillman, S., Skeie, R. B., Spracklen, D., Stavrakou, T., Steenrod, S. D., Takemura, T., Tiitta, P., Tilmes, S., Tost, H., van Noije, T., van Zyl, P. G., von Salzen, K., Yu, F., Wang, Z., Wang, Z., Zaveri, R. A., Zhang, H., Zhang, K., Zhang, Q., and Zhang, X.: The AeroCom evaluation and intercomparison of organic aerosol in global models, Atmos. Chem. Phys., 14, 10845-10895, doi:10.5194/acp-1410845-2014, 2014.

Uppala, S. M., Kållberg, P. W., Simmons, A. J., Andrae, U., Bechtold, V. D. C., Fiorino, M., Gibson, J. K., Haseler, J., Hernandez, A., Kelly, G. A., Li, X., Onogi, K., Saarinen, S., Sokka, N., Allan, R. P., Andersson, E., Arpe, K., Balmaseda, M. A., Beljaars, A. C. M., Berg, L. V. D., Bidlot, J., Bormann, N., Caires, S., Chevallier, F., Dethof, A., Dragosavac, M., Fisher, M., Fuentes, M., Hagemann, S., Hólm, E., Hoskins, B. J., Isaksen, L., Janssen, P. A. E. M., Jenne, R., Mcnally, A. P., Mahfouf, J.-F., Morcrette, J.-J., Rayner, N. A., Saunders, R. W., Simon, P., Sterl, A., Trenberth, K. E., Untch, A., Vasiljevic, D., Viterbo, P., and Woollen, J.: The ERA-40 re-analysis, Q. J. Roy. Meteor. Soc., 131, 29613012, doi:10.1256/qj.04.176, 2005. 
Vestreng, V., Myhre, G., Fagerli, H., Reis, S., and Tarrasón, L.: Twenty-five years of continuous sulphur dioxide emission reduction in Europe, Atmos. Chem. Phys., 7, 3663-3681, doi:10.5194/acp-7-3663-2007, 2007.

Volkamer, R., Jimenez, J. L., San Martini, F., Dzepina, K., Zhang, Q., Salcedo, D., Molina, L. T., Worsnop, D. R., and Molina, M. J.: Secondary organic aerosol formation from anthropogenic air pollution: Rapid and higher than expected, Geophys. Res. Lett., 33, L17811, doi:10.1029/2006GL026899, 2006.

Walters, D. N., Best, M. J., Bushell, A. C., Copsey, D., Edwards, J. M., Falloon, P. D., Harris, C. M., Lock, A. P., Manners, J. C., Morcrette, C. J., Roberts, M. J., Stratton, R. A., Webster, S., Wilkinson, J. M., Willett, M. R., Boutle, I. A., Earnshaw, P. D., Hill, P. G., MacLachlan, C., Martin, G. M., Moufouma-Okia, W., Palmer, M. D., Petch, J. C., Rooney, G. G., Scaife, A. A., and Williams, K. D.: The Met Office Unified Model Global Atmosphere 3.0/3.1 and JULES Global Land 3.0/3.1 configurations, Geosci. Model Dev., 4, 919-941, doi:10.5194/gmd-4-919-2011, 2011.
Wild, M.: Global dimming and brightening: A review, J. Geophys. Res., 114, D00D16, doi:10.1029/2008JD011470, 2009.

Wild, O., Zhu, X., and Prather, M. J.: Fast-J: Accurate Simulation of In- and Below-Cloud Photolysis in Tropospheric Chemical Models, J. Atmos. Chem., 37, 245-282, doi:10.1023/A:1006415919030, 2000.

Woodward, S.: Modeling the atmospheric life cycle and radiative impact of mineral dust in the Hadley Centre climate model, J. Geophys. Res., 106, 18155, doi:10.1029/2000JD900795, 2001.

Yu, H., Kaufman, Y. J., Chin, M., Feingold, G., Remer, L. A., Anderson, T. L., Balkanski, Y., Bellouin, N., Boucher, O., Christopher, S., DeCola, P., Kahn, R., Koch, D., Loeb, N., Reddy, M. S., Schulz, M., Takemura, T., and Zhou, M.: A review of measurement-based assessments of the aerosol direct radiative effect and forcing, Atmos. Chem. Phys., 6, 613-666, doi:10.5194/acp-6-613-2006, 2006. 